University of Louisville

ThinkIR: The University of Louisville's Institutional Repository

Electronic Theses and Dissertations

$5-2004$

\title{
A model racing plant : founding and economic history of Keeneland racetrack.
}

Scott A. Carmony 1967-

University of Louisville

Follow this and additional works at: https://ir.library.louisville.edu/etd

\section{Recommended Citation}

Carmony, Scott A. 1967-, "A model racing plant : founding and economic history of Keeneland racetrack." (2004). Electronic Theses and Dissertations. Paper 210.

https://doi.org/10.18297/etd/210

This Master's Thesis is brought to you for free and open access by ThinkIR: The University of Louisville's Institutional Repository. It has been accepted for inclusion in Electronic Theses and Dissertations by an authorized administrator of ThinkIR: The University of Louisville's Institutional Repository. This title appears here courtesy of the author, who has retained all other copyrights. For more information, please contact thinkir@louisville.edu. 
"A MODEL RACING PLANT": FOUNDING AND ECONOMIC HISTORY OF KEENELAND RACETRACK

\author{
By \\ Scott A. Carmony \\ B.A., University of Louisville, 1993
}

\begin{abstract}
A Thesis
Submitted to the Faculty of the

Graduate School of the University of Louisville

In Partial Fulfillment of the Requirements

For the Degree of
\end{abstract}

Masters of Arts

Department of History
University of Louisville
Louisville, Kentucky

May 2004 
"A MODEL RACING PLANT": FOUNDING AND ECONOMIC HISTORY OF KEENELAND RACETRACK

\section{By}

Scott A. Carmony

B.A., University of Louisville, 1993

A Thesis Approved on

April 19, 2004

by the following Thesis Committee:

Thesis Director 


\section{ABSTRACT \\ "A MODEL RACING PLANT": FOUNDING AND ECONOMIC HISTORY OF KEENELAND RACETRACK}

Scott A. Carmony

May, 2004

This thesis is an economic and historical examination of Keeneland racetrack in Lexington, Kentucky. The material commences with a historical overview of the role of sport and recreational activities in the United States. Putting sport and leisure activity in the context of mirroring changes in society is the focus of the section. Furthermore, this material explores the general sporting environment in United States history, moves to horseracing's place within that history, then concludes with the scope of the horse and horseracing in Kentucky, and particularly, the Bluegrass region of central Kentucky. The following material focuses on the unique and remarkable history and economic survival of Keeneland racetrack in Lexington, Kentucky. The historiography of United States sport and leisure activities, horseracing, and the horse industry in Kentucky is surveyed in the material.

The thesis is divided into five sections, covering the history of sports and horseracing in the United States, the founding of Keeneland racetrack, and the survival of Keeneland as a small, cosmopolitan track amid the larger corporate tracks prevalent in the horse industry of the twenty-first century. The Introduction and Chapter One gives an overview of the history of sports and recreational history and horseracing in the United 
States. Chapter One concludes with the history of the horse and horseracing in Kentucky and the Bluegrass region of central Kentucky. Chapter Two focuses on the horsemen of central Kentucky's founding and opening of the Keeneland Association and Keeneland racetrack. Chapter Three explores the economic survival of the small, cosmopolitan track within the context of the multi-billion dollar horse industry of the twentieth-century, continuing in the first years of the twenty-first century. The Conclusion highlights the main thesis and arguments for each chapter. This material links sport and leisure activity, through the oldest sporting event in the United States (horseracing), within the context of a comparison between sport and change in society. 


\section{TABLE OF CONTENTS}

\section{PAGE}

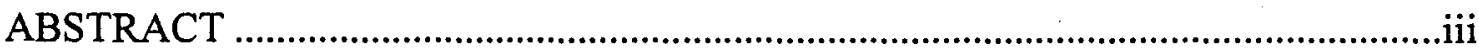

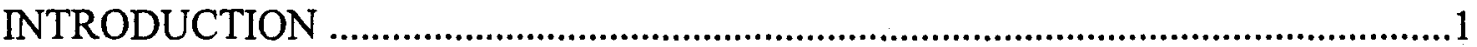

The Role of Sport and Recreation in America ...........................................................

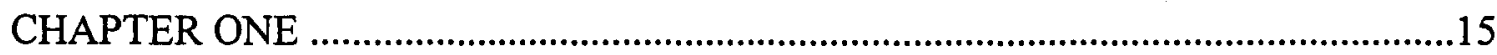

The Horse and Horseracing in Kentucky ...........................................................33

Lexington's Horse and Racing Traditions ...............................................................38

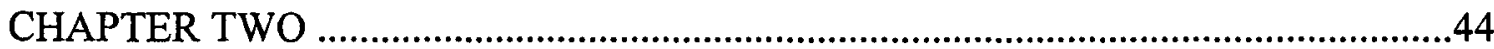

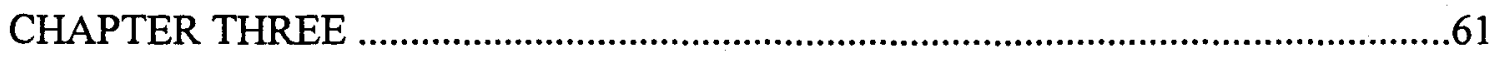

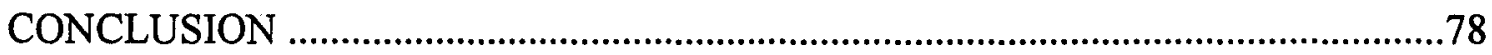

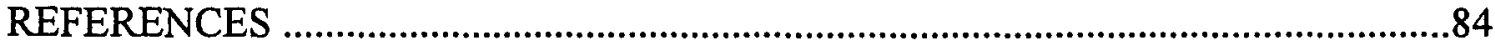

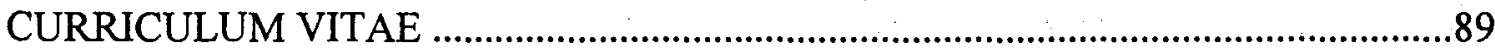




\section{INTRODUCTION}

Sport and recreational activities have an extensive and important history of their own within United States history. America's sporting traditions reflected societal values and images from the earliest colonial times to the present. Participation in sport and leisure activity grew with the passing of each decade, especially in the twentieth century - - - a trend that shows no sign of slowing down. All segments of American society participated in sport and recreational activities, both as observers and participants. Withstanding such effects as war, religious warnings, and economic catastrophes, recreation remained an important component of United State's popular culture. This introduction examines the role of sport and recreation in United States social history. The impact of the emergence of societal class and occasional religious suspicion of recreation on the evolution of sport and leisure is discussed in this section. In addition, the evolution and re-defining of sport from their English traditions by Americans is examined. The immense historiography of sport and recreation and the historical context of sport in United States society are analyzed as well.

From the settlement at Jamestown in 1607 to the present day, Americans have raced horses. Horseracing constitutes the oldest and most celebrated recreational activity of colonial America and it maintained its status as "the sport of kings" throughout the United States history. 1 While originally reserved for upper class participation, rarely has

a sport extended to all boundaries of classes like horseracing. Raising horses in America 
became a recreational byproduct of the tidewater regions of Virginia, Maryland, New York and the Carolinas. Yet nowhere did horse breeding or desire for racing exist more so than in Kentucky. Chapter One analyzes the unique place of horse racing in United States recreational history. That chapter focuses on the heritage of the sport from England through its growth into the billion-dollar industry of the early twenty-first century. The historiography of the horse in the United States and the horseracing industry is analyzed as well.

The second section of Chapter One deals with the history of the horse in Kentucky and the thriving industry that followed. The vital role of geography is examined in this section. In addition, this material explores the first horses that settlers and racing enthusiasts brought from Virginia and England. The expansion of the racing and breeding industry by horsemen of Kentucky concludes this section. A third segment of Chapter One probes information on central Kentucky's Bluegrass region, particularly Lexington, as the major region in the United States for the thoroughbred industry. The second and third segments of Chapter One will focus on racing in Kentucky and the enormous growth of the horse industry throughout the state. The final section of the chapter concludes with the closing of the Kentucky Association racetrack in Lexington. This event led to the formation of Keeneland and the most unique event in horseracing history.

Enthusiasm for horses in Kentucky was unparalleled anywhere else in the United States. From racing on the first city streets of Lexington to the "greatest two minutes in sports," the horse as industry became synonymous with, and grew in stature, in Kentucky. Centered in the Bluegrass Region of central Kentucky, professional 
associations, education programs, and racing venues flourished in the state as the love of horses evolved into a billion-dollar industry. The most unique racetrack in the United States emerged in the heart of Bluegrass country. Keeneland Race Course in Lexington, Kentucky was an anomaly in its origins and in its purpose. Designed and constructed out of the desire to improve the thoroughbred breed of horse and the industry built around it, Keeneland's founders sought to build a model racetrack unlike any in the United States. The genesis for the ideal track lay in the central Kentucky horsemen's desire to construct a home for the Kentucky horse, its owners, trainers, buyers, sellers, jockeys, and breeders. What made the idea of Keeneland the most unique in United States history was that its founders established the course as a not-for-profit venue. The Second and Third Chapters focus on the formation of Keeneland and the association of men that had the vision to create a model thoroughbred center. How Keeneland has survived as a small, cosmopolitan track among the large, corporation influenced venues of the twenty-first century is explored in the final chapter.

\section{The Role of Sport and Recreation in America}

The United States has a long sporting tradition. From the Puritans in Massachusetts Bay throughout the early United States, recreation formed an integral aspect of society and culture. Americans' quest for leisure and recreational activities began with the first settlements in the colonies and continued to grow into the popular modern sports. Scholars of sport noted the cause for celebration and the need for distraction from the workingman's toil that sport provided. The historiography of sport surged in the 1980's as sport and leisure historians sought to explain the history and emergence of the massive modern phenomenon. Sports historian Richard Lipsky wrote 
in his 1981 book, How We Play the Game: Why Sports Dominate American Life, "The Sportsworld creates an extremely meaningful world for those who inhabit its arenas ... as a dramatic and symbolic world, the Sportsworld has its own plots, scenes, characters, and settings." 2 The explosion of literature in the eighties came at the dawn of the multimillion dollar athlete and the billion dollar sport franchises and events. The popular culture of the sporting arena expanded to unparalleled heights during the decade, as did the literature that followed. In the 1980's, historians Donald Mrozek and Benjamin Rader stood out as writers and commentators of the popularity of sport and leisure. They analyzed and placed the popularity of leisure activities within their historical context. 3 Historian Steven A. Riess published the most useful collection of primary source documents in his 1984 work. 4 His work provided vast material on how the historical experience of recreational activities affected the myriad types of American societies. Large numbers of historians also wrote in this period about race, gender, and various cultures that participated in, and contributed to, the American sporting tradition. Few historians wrote on these topics prior to the late 1970s. The growth of political correctness and awareness of minority groups undoubtedly affected the growth of literature during the decade. The secondary source material in the field of sport and recreation was enormous, and for the most part, useful for historical research. An examination of nearly every aspect of the field was surveyed and written by various social and institutional historians such as Radar, Mrozek, and Riess. The commentators of American recreational activities also noted the greed, class divisions, and manipulation in sport as reflective of the worst aspects of United States culture. But in whatever aspect 
writers and historians have researched, their scholarship reflected that sports and recreation formed one of the nation's vibrant cultural institutions.

From the pre-colonial times through the present, recreational and professional sport contributed to the social and economic health of society. Recreation and sport of all varieties formed during the United States' infancy. Historian Benjamin Radar stated in his book, American Sports: From the Age of Folk Games to the Age of Spectators, that colonial pastimes "were the result of the interaction between the customs the people brought with them and New World circumstances." 5 The early, organized sports of the seventeenth century reflected the coarse aspects of the agricultural lifestyle. Foot races, wrestling, kicking the hat, and marksmanship events constituted the common man's recreational sports of choice in the seventeenth and eighteenth centuries. These ordinary people participated in games such as stick fighting, animal baiting, and cockfighting that found their place in early United States sports tradition as the spectator became more involved as both primary participants and secondary cooperatives. While the few upper class merchants and planters clung to their European traditions of riding, fox hunting, fencing, and card playing, room existed in colonial America for all groups of recreation. The English upper class sporting traditions did not take hold among the early colonists and would not influence inhabitants of the settlements until the eighteenth century. The lack of wealth among the settlers of the colonies did not allow them to imitate the English gentry.

Sport and leisure activity found a place in all of the early colonies. The industrious Puritans, for example, whose intent for coming to the New World, according to sports historian Peter Levin, was to establish "a corporate, religious community," 
allowed for the participation in sporting activities. 6 Levin's 1989 work, American Sport: A Documentary History, included "The Perils of Ball-Playing," written in 1651 by Puritan and Plymouth Colony Governor William Bradford. This document contained the following insight into the early colonial quest for village pastimes and leisure sports brought with them from England: "So he led away y' rest and left them; but when they cam home at noon from their worke, he found them in y' streete at play; openly; some pitching y'barr, \& some at stooleball, and suche like sports." 7 The town leader admonished the participants for their work distraction, but it was clear that the fervor of the sporting life lay in the earliest American societies. Benjamin Rader commented such incidents of Puritan play "suggests several forces which have shaped American sport," among which were the immigrants desire to keep alive, at least in some form, the English sporting traditions. 8 Their participation in these events allowed the settlers the opportunity, or a distraction, from the daily rigors in their toil for existence. But in addition, Radar suggested, Puritan leader's rebuffs of the distraction sports fostered "inhibited the growth of colonial sports" and created "an exceptionally sober and industrious people" that would not change until the eighteenth century gentry class emerged. 9

The Puritans in New England enacted legislation that required stringent observance of the Sabbath and abolished or restricted holidays and traditional forms of recreation. The colonists of Massachusetts instituted a fine for anyone who feasted or refused to work on Christmas Day. 10 Nonetheless, the transplanted Englishmen in the villages of New England religious communities clung to the varied sporting and leisure traditions of their homeland. As long as the recreation of the Puritan colonists did not 
distract the participants from keeping God before their eyes and first in their thoughts, the leaders of the Puritan communities approved and permitted participation. 11

Much of the research on the history of sport and recreation included material on the Puritans and their view on the subject. Depending on the Puritan minister and congregation studied, most research suggested that Puritan leaders and societies tolerated forms of recreation that were beneficial, morally acceptable in the community, and participated in with moderation. Historian Nancy Struna argued in her 1977 article, "Puritans and Sport: The Irretrievable Tide of Change," that Puritans had a proper time and place for their sporting activities. She wrote that, to Puritans, "sport might thus be as mutually beneficial to man as eating and drinking, especially if pursued in lawful forms and attentive to order." 12 She acknowledged in her article that "magistrates [in Massachusetts] sought to limit these occasions and, in effect, may have restricted participation" but further wrote, "the occurrence of sport was very real, reflecting both values and diversity within that society." 13

By the beginning of the eighteenth century, colonists became more sympathetic to sporting events as new social statuses emerged. Common colonists sought recreation through such varied sports as races, sledding, lawn bowling, and hunting. Taverns and inns became commonplace as centers for participation in games and relaxation. The want of sport and recreation by the colonists had emerged by 1750 . For example, organizers of the Hanover County Fair in western Virginia, established in 1737, supported a horse race for five pounds, as well as wrestling and cudgeling (boxing) matches. 14 Historian Ruth Painter, in her article, "Tavern Amusements in Eighteenth Century America," wrote of a Virginia clergymen who stated the taverns "had become the common ... rendezvous of 
the very dregs of the people ... where not only time and money are vainly and unprofitably squandered away, but where prohibited and unlawful games, sports, and pastimes are used, followed and practiced ... namely cards, dice, horse-racing, and cockfighting." 15 Travelers from other towns, as well as England, brought tales of various leisure events that further enhanced the participation in such activities. Radar and Levine attributed much of this sympathy toward sport to the Middle and Southern colonies less rigid religious practices and its vast spreads of land. Inhabitants of these colonies enjoyed some of the same village pastimes of the New Englanders, but added horse racing, wrestling matches, and various other physical contests that gained footholds on the sporting landscape.

The eighteenth century also ushered in the period when the colonial landowners developed a separate division of leisure based on their landed wealth and the wealth of the larger city merchants. The Middle colonies and the large landowners of the Tidewater regions in the South made up the members of this new gentry class. These gentry delighted in such sports as horseracing, cricket, billiards, and hunting. Such people thought themselves better than the common man. Their social point of view led the gentry's class to participate in the "gentlemanly" games of billiards, fencing, lawn bowling, and horseback riding. 16

The Great Awakening religious movement of the 1730s and 1740s hindered the expansion and satisfaction that sport and leisure provided the colonists. A stricter adherence to the submission of God formed the basis of this evangelical movement and its participants believed salvation was not guaranteed by belief nor earned by deeds of man. Followers of the movement believed salvation was a gift from God and from the 
evils of the world which included the traditional games and sports partaken by the colonists and had to be avoided. Evangelical orators such as George Fox, founder of the Society of Friends (Quakers) and George Whitefield traveled the colonies thundering against the evils of diversions like recreational sports and leisure, or "such entertainments ... contrary to the whole tenor of the Gospel of Christ." 17

As the eighteenth century came to a close, Americans re-defined sport and leisure activities from their English beginnings and molded the games in a distinct American image. As new social classes and ways of conceptualizing religious standards evolved, so too did the sporting activities in which American's participated. Hunting, for example, held different values and meaning to different classes of people. The owners of land hunted for sport and enjoyment while the spectator and participant hunters poached for food to feed themselves or their families. Class divisions widened in the nineteenth century. Boxing was a classic example of this social division. Illegal bare-knuckle fighting characterized the sport of the working class man while the upper class viewed the sport as barbarous and crude.

Americans did not completely forget the religious tie-ins to sporting events in the first half of the nineteenth century. Historian Edwin A. Miles wrote in his 1972 article, "President Adams' Billiard Table," that North Carolina Representative Samuel Carson stated President John Quincy Adams's purchase of a secondhand billiard table should "shock and alarm the religious, the moral, and the reflecting part of the community." 18 Benjamin Rader stated that views such as Carson's "spotlighted the beginnings of a new pattern of culture in the United States. Victorianism ...."19 Nonetheless, large portions of Americans found saloons, gambling, and sport to their liking. Sports became 
more organized than in the previous century and the interest of the spectator emerged as a new phenomenon. As the move west from the original colonies progressed and the populations of cities increased, large numbers of spectators came to watch the recreational and sporting events. For example, foot racing, prize fighting, and wrestling, although lacking in regulatory organization at the time, became spectator-oriented events in such early and mid-nineteenth century American cities as Philadelphia, Boston, New York, and Washington. Nonetheless, inhabitants of the rural areas still participated in the traditional rough-hewn games of shooting and physical ability contests, usually for jugs of whiskey or sides of meat. The inhabitants of the rural areas lived by the seasons of the year, rather than a timepiece, and needed their leisure time traditions to relieve the isolation and tedium that urban dwellers rarely experienced.

By 1850 , the upper and middle classes formed voluntary associations, or clubs, to promote a particular sport. Middle-class persons approved of the idea of clubs and opposed rural-oriented games that featured a more violent tone such as wrestling and bare-knuckled fights. American sporting society had developed by the 1850 s and it held little resemblance to English traditional sporting activities. The United States had undergone a transformation in wealth accumulation, working environments, and transportation that led to increased leisure time for many of its citizens. A thriving sport culture emerged in the face of increased population, mild religious attempts at temperance, and the clear presence of social class distinctions.

Sports historians Douglas A. Noverr and Lawrence E. Ziewacz wrote in, The Games They Played: Sports in American History, 1865-1980, that "the post-Civil War period witnessed an athletic revolution." 20 New faces from high birth rates and massive 
European immigration led to population increase in the late nineteenth century. By 1860 , the population of the United States stood at thirty-two million, up from the one and a half million of 1750.21 Americans began participating in a wider variety of sporting activities. While sports and leisure declined during the Civil War, the Gilded Age of the 1870 s through the dawn of the twentieth century ushered in a heightened enthusiasm for sport that grew exponentially through modern times. In their book, Noverr and Ziewacz argued that newly formed sports associations formed during the Gilded Age, such as the Rowing Association of American Colleges, the Untied States Lawn Tennis Association, and the United States Golf Association, "tends to confirm this period as crucial to American sports development." 22 Nover and Zeiwacz included work on the development of women's sports and inclusion of women in established sports as revolutionary, as well. The authors pointed to women's participation in tennis and golf, for example, which expanded the influence of women in sport beginning in the midnineteenth century. Sports historian John R. Gerdy argued in, Sports: The All-American Addiction, that "institutionalized sport that even remotely resembled organized sport of today, with its layers of regulatory bodies, vast promotion networks, and mountains of records and statistics, simply did not exist in America before the late 1800's." 23 Participation in, spectacle in, and organization of sport and recreation flourished in the last half of the nineteenth century.

Historian John Rickards Betts stressed in his America's Sporting Heritage: 18501950, "the main features of modern sport appeared only in the middle years of the nineteenth century." 24 Betts argued that the decline of the Puritan influence, the impact of immigration, and the large movement of Americans from the rural to the urban setting 
"aided in promoting sports" during this time period. 25 Betts also commented that advanced technology such as railroads, telegraphs, electricity, and cameras were key technological advances that aided sports awareness. While the heightened awareness and participation in sport, particularly at the collegiate level with sports such as football and baseball, rose during the period, so too did the workday hours for most Americans who moved in to urban work environments. While the workday expanded, the wages for most factory workers were paltry. Historian Gerald Grob observed in, Workers and Utopia, that "each individual was thrown upon his own resources" and "the community.. . had disintegrated." 26 Benjamin Rader argued in his 1977 article, entitled "The Quest for Subcommunities and the Rise of American Sport," sport-related activities, most notably everyday sports clubs, reconnected the notion of communities washed away by the urban factory environments. Rader acknowledged that some sports clubs were reserved for the upper classes, but that they were multipurpose in that they not only promoted sport, but the clubs "assumed some of the traditional functions of the church, the state, and the geographic community." 27 The Young Men's Christian Association (YMCA) and the Young Women's Christian Association (YWCA) had been founded by the end of the century as well. Clearly, Americans expanded sport and leisure to unaccustomed prominence by the end of the nineteenth century. By 1900, Americans ushered in their sports and leisure space to modern times.

Historian Donald Mrozek published an engaging book, Sport and American Mentality: 1880-1910, in which he examined the role that sports and recreation played on the mindset of American culture during this crucial era in the field of sports history. He wrote that at the beginning of the twentieth century, "several major changes in 
American culture affected the perception of sport ...." 28 One of these changes was the emergence of a heightened nationalism. A second transformation was the changed role of women in sport, and a third transformation was the favorable opinion in American society of an "energetic, dynamic style in all aspects of life." 29 Mrozek wrote that at the beginning of the twentieth century a "final acceptability of sport" existed that "transcended the disputed criteria and purposes set out by groups that never could have agreed completely on these matters in any case." 30 A leisure-spectator sporting mass formed in the early decades of the twentieth century as popular sporting events such as baseball and football grew in popularity and participation increased throughout the first half of the century.

In the late twentieth century sporting world, millionaire clients and million dollar businesses fed the salaries and overhead costs of gigantic sports franchises and participants. The cost of admittance into major sporting events was usually reserved for the upper and middle classes. For example, the price for an average seated ticket to a Major League Baseball game at the end of the twentieth century was nearly thirty dollars. 31 Tickets to major sporting events such as playoff games or championship events fell well into the hundreds of dollars. Sports evolved to enormous business ventures in the twentieth century. All aspects of major sports operations centered on the economic success of the organization. By the end of the twentieth century, roughly twenty percent of total personal expenditures for consumption went into recreational activities. The sport-athlete at the dawn of the twentieth century committed himself or herself to the values of character building, self-discipline, and mental and physical fitness. The transformation from the amateur athlete to the modern day athlete was a twentieth 
century phenomenon. Without question, Americans regarded college and professional athletes in the highest stature by the end of the twentieth century. Millions applauded the successful athlete, and demeaned the unsuccessful, as a glorified personality above the most famous politicians, religious leaders, and educators of the day. All of this evolution applied across all disciplines of sport except horse racing. While horseracing evolved as a major United States industry, a program, two dollars, and a pencil were all that was needed for active participation in the sport of kings. 


\section{CHAPTER ONE \\ THE SPORT OF HORSERACING IN AMERICA}

Horseracing constitutes the oldest sport and recreational activity in United States history. Sports historians have traced the tradition and excitement of horseracing back to the entertainment the races provided to the first settlers at Jamestown during the first decade of the seventeenth century. Although these races were unorganized events, the horses of Jamestown provided historians with a preview of one of the settler's favorite English traditions. Colonial horsemen began the importation of thoroughbred stock from England thereby expanding their passion for horseracing. With the passing of each decade, the recreational activities of racing and of gambling on the horse developed into an enormous industry. The popularity of the sport increased in participation, organization, and regulation. By the twenty-first century, the horse industry was a billion-dollar industry participated in by spectators, owners, breeders, and gamblers throughout the world. This chapter examines the rise in popularity of horses and horseracing in the United States. The material focuses on the horseracing traditions brought by settlers from England to the popularity of racing in modern times.

No sport in the nation's history extended to the reaches of all classes or generated the excitement for sport earlier in United States history than horseracing. In America's Sporting Heritage: 1850-1950, historian John Rickards Betts argued that "the roots of our sporting heritage lie in the horse racing and fox hunting of the colonial era." 32 
of Sport in America, observed that "horse racing generated far greater interest ... than did household games ... these contests were preeminently a social drama." 33 The horse and horseracing have generated a sweeping historiography. The literature ranged from the horse in Mesopotamia to the 2003 Kentucky Derby winner Funny Cide. Numerous commentators, historians, researchers, and sports fanatics have written about the sport. In 1976, Dean Alfange wrote the most useful examination of the entire horse industry in his The Horse Racing Industry. His book was an absorbing work on the proliferation of the horseracing industry and how it evolved. Alfange's work proved instrumental in understanding the growth and evolution of horseracing into a billion dollar industry. The Jockey Club published the most voluminous material on the role of the horse and racing in the United States in Racing in America: 1665-1979. This six-volume reference work was vital in researching the scope of the horse and racing throughout the history of the United States. Much of the secondary literature was published in the 1960's, and even more so in the 1970's. This burst of interest in the sport coincided with Secretariat's enormously popular run to the Triple Crown. Publishers brought forth numerous collector books and feel-good works about horses, racetracks, and horse breeding, although these sources were not much help to the historian. As the scope of the field of research narrows (e. g. racing in Kentucky, formation of Keeneland), so, too, does the secondary source material. Historians researched and published little on the scope, role, and place of the horse or horseracing in Kentucky.

Racing historian Lynn S. Renau's Racing Around Kentucky was one of the best sources for Kentucky historical material. But Renau located most of her research in 
periodicals and museum references, such as The Thoroughbred Record and the Thoroughbred Racing Communications media updates. The aggregate numbers of books was not an issue, but rather their usefulness to historical research proved challenging. People have written numerous books and published a variety of works on the history of the Kentucky Derby, but such popular literature was published for the casual, social reader rather than the professional historian. Many edited editions, articles, and periodicals aided in the discovery of information on Lexington history and the formation of Keeneland. This material aided the research into the history of Keeneland. Overall, the literature on Kentucky and Lexington's racing industry and tracks is barely adequate in supplying historical research in the field.

While dubbed "the sport of kings" from the English tradition for its nobility's favorite diversion, organized horse races developed in the colonies as early as 1665 in New York. Match races of English-bred horses formed the format of these races. Colonial newspapers and pamphlets included information on such races in the Carolinas as early as 1734, in Virginia in 1739, and in Maryland in 1745. 34 While settlers used the races and horses for the recreation and gambling habits of the colonial upper class, these matches constituted the origins of the twelve-horse event of modern times.

Historian Francis Barnum Culver examined the genesis of the horse industry in America in, The Blooded Horse of Colonial Days. Culver stated that "to this day the influence of those early importations and of the spirit of emulation on the part of the American gentlemen of colonial days is felt in this country, and the good seed first sown in Maryland and Virginia has brought forth good fruit, and that abundantly." 35 Benjamin Rader stated in American Sports: From the Age of Folk Games to the Age of 
Spectators that "above all, the great planters had a passion for wagering on horse races." 36 The settlers kept their horses, mainly quarterhorses, for races nearly one hundred years before colonial horsemen imported their first English horse for the sole purpose of running races. Tavern dwellers argued the merits and breeding of their own horses that usually ended with a horseracing event. Seventeenth and eighteenth century innkeepers sponsored match races to draw business to their establishments. But as the common colonial man participated in the sport of kings via the inns and taverns, the English aristocratic racing traditions were kept intact in the New World. Virginia provided the best example.

In 1611 , the first horses arrived in Virginia at Jamestown. Colonists protected these seventeen horses from the same fate of six horses of the original Jamestown settlement, which the settlers ate for survival. Governor Thomas Dale issued a decree that no man could kill any livestock, which included the horses. Sailors on supply ships sailing to the Virginia colony and agents for the Virginia Company authorized horse cargo as part of their inventory. 37 English sailors to Virginia brought horses to the colony for labor tasks, such as hauling wood and logs as the colony's population increased. Throughout the 1630's and 1640's, the settlers continued their English tradition of horseracing. Quarter horse racing generated the most interest among Virginians. Used as entertainment from the rural lifestyle of farming, clearing land, and daily chores, the speedy, yet stamina-short horse provided a recreational activity to all classes of early colonial society. The Accomack County Court records showed "a very poore Man," Thomas Davis, had foolishly wagered and lost five hundred pounds of tobacco or a cow and a calf in a horse race. 38 
Unrest in England in the 1640s through the 1660s contributed to the horse's popularity in the early colonies as well. By the mid-seventeenth century, a revolution and Civil War (1640-1660) in England was fought and Oliver Cromwell stamped his Puritanical image on England. Oliver Cromwell's England was a somber, militaristic endeavor that banned everything from leisurely walks on Sundays to spoken opposition of his rule. In 1654, Cromwell issued a proclamation which outlawed racing for six months. Cromwell suspected that England's racecourses doubled as Cavalier meeting places. He also feared that the tracks encouraged wagering among the participants. 39 Many of the individuals and families who did not support Cromwell's Puritanical ideas left England for the New World. The families of the exiled Englanders settled in the Tidewater regions of Virginia, Maryland, and South Carolina. Sir William Berkeley, the governor of Virginia "had industriously invited many gentlemen and other thither, as a place of security, where they might live plentifully." 40 By 1650 , the number of Virginia colonists doubled from the previous decade to 17,000 , and, by the mid-1660s, doubled again to nearly $35,000.41$ The knowledge of the horse and their thirst for racing the colonists brought with them from England was invaluable and placed an indelible stamp on the horse breeding and racing legacy in America. Among these traditions were those of the thoroughbred breed of horse.

All thoroughbred stock in America and throughout most of the racing world today traced its male lineage to three Arabian stallions; the Godolphin Arabian, the Darley Arabian, and the Byerly Turk. The research on the origin of these three foundation thoroughbreds leaves much unclear. Historians gave no names for the horses and these horses appear in the historical research only as Godolphin Arabian, Byerly Turk, and 
Darley Arabian. From the best research by thoroughbred historians, the Turk was foaled around 1679.42 Little else is known of this horse except that he received his name from Captain Byerly, a veteran of the Irish Wars in King William's wars. Byerly captured the horse from an enemy officer at the Battle of Buda in 1688. A mixture of Arab and Persian breeds, the Byerly Turk stood at stud until about 1698 .

The Godolphin Arabian was foaled in Yemen in 1724. His owner sent him to Louis XV of France in 1731. Louis XV sold the horse for a "miserable sum" as a water cart horse in Paris. 43 An Englishmen and Derbyshire Quaker named Edward Coke discovered the horse in the streets of Paris and marveled at the Arabian's magnificence. Apparently, King Louis XV disliked Arabians and sold the horse almost as quickly as he received him. Coke paid sixty-eight francs for the then nine-year-old horse and returned with the horse to London where he, in turn, sold it to a close friend. John Gilmer Speed's book, The Horse in America, suggested the date of the Arabian's arrival in England was 1725. Coke's friend could not break the Arabian and sold the horse once more. This time, the horse sold for the sum of twenty-five guineas to the Lord Treasurer of London, the Earl of Godolphin. The Godolphin Arabian stood stud at the Godolphin estate in England and died at the age of twenty-nine, father of many successful runners at the Newmarket Race Course of England. He is buried under the stable gateway at GogMagog horse estate, near Cambridge. Among the Godolphin line of blood were the great Man $O^{\prime}$ War and his son War Admiral. 44

Most research showed the Darley Arabian was foaled around 1700 and Thomas Darley bought the horse in the North African port city of Aleppo three or four years later. Darley sent the stud to his brother or father (which, was not clear) in Yorkshire, England 
in 1704. 45 Ernst de la Grange wrote in Horse Racing Through the Ages, that the Darley family did not bring the Arabian to England until 1723. He asserted that John Darley, Thomas' brother, gave the horse its name, Darley Arabian. William Ridgeway in The Origin and Influence of the Thoroughbred Horse, maintained the Darley Arabian was foaled in 1710. Most horse researchers and historians use the 1700 and 1704 time frames. The Darley Arabian sired Flying Childress, which became one of the greatest racehorses in English history. 46

Colonial Virginia flourished as a breeding and racing core of the thoroughbred breed of horse. Virginians imported thoroughbred bloodline horses from England for the purposes of adding to, and improving on, the general stock of horses in the colony. For example, Colonel John Baylor of Virginia purchased the horse Fearnaught for one thousand guineas. The horse gained the reputation as "the Goldolphin Arabian of the Old Dominion." 47 Horsemen of Virginia also brought to Virginia the English horse Janus, the latter son of the Goldolphin Arabian. Culver claimed these Virginia horses "are entitled to much credit when we come to trace the history of the blood-horse in America." 48 Virginia colonists established racetracks that displayed their horse's ability in towns like Richmond, Alexandria, Williamsburg, and Fredricksburg.

By the mid-1660s, wealthy Virginia aristocrats dominated horseracing. Unlike settlers of the religious colonies of Massachusetts and Pennsylvania, the Virginia landowners capitalized on the valuable crop of tobacco. Virginia planters made their fortunes in the exporting of the crop. At the same time, the residents emulated the mother country's desire for the turf sport of horseracing and the races separated the social orders. Radar argued that the gentry's involvement in gambling and horseracing "had a more 
profound impact upon the future of American sport" than any of the other recreational activities mentioned. 49 John Wallace added that "Virginians were a horse-racing people from the start, and it is impossible to tell how long before racing first commenced, but probably just as soon as two neighbors met ... this racing ... pervaded the whole colony." 50 These races varied from four-mile runs down to a quarter-mile sprint, the choice of distance for most of the races. Historian T. H. Breen argued in his article, "Horses and Gentlemen: The Cultural Significance of Gambling Among the Gentry of Virginia," that "the quarter-horse races of Virginia were intense contests involving personal honor, elaborate rules, heavy betting, and wide community interests ...." 51

The aristocratic class of Virginians took their racing seriously as demonstrated by Virginia Court records from 1689. Dated "August $1^{\text {st }}, 1689$," the Henrico County court record provided succinct evidence of a match race set up by horse enthusiasts in the Virginia colony. The record stated that "Mr. Wm. Epes" and "Mr. Stephen Cocke," apparently the riders of the horses, agreed that "each horse was to keep his path, they not being to crosse unlesse Stephen Cocke could gett the other Riders Path" and "that they were not to touch neither man nor horse." 52 At issue was the honor and integrity of the makeshift rules, put in place by the owners of the horses, that the riders would not cross each other's path after the first two to three jumps or bump each other along the way. In addition, the dispute revolved around the seriousness of the event and the sum of money - - - ten shillings - - - wagered by the owners of the horses. Cocke's horse won the race but Epes challenged the result on the grounds that Cocke broke the rules of the race made by the owners of the horses. The court ruled against Mr. Cocke on the grounds that he crossed the path from the starting line sooner than the agreed upon rule of two to three 
strides of the horse. While the class lines in other recreational sporting events in colonial times widened, the distinctions in horseracing began to blur. The first written announcement for a thoroughbred race by the Virginia newspapers appeared in 1739. Owners of the horses held the unusual eight-horse-race at Williamsburg for a saddle valued at forty shillings. 53 Second place was a bridle and third place carried a prize of a whip. The organizers of the race did not publish the results.

New York was another colony absorbed by racing. Organizers of horse races developed quarter horse racing in the colony as early as 1665 , one year after the British seized New York from the Dutch. That year, Governor Richard Nicolls established the first known racetrack in America on Long Island. Nicolls named the new racecourse at Hempstead Plains, "Newmarket," after the famous course in England. The heavy shouldered equines ran full speed for a few hundred yards and up to a quarter of a mile on the track. The unregulated events, with little or no rules, were frequent. Operators of the one-quarter mile races, and thus, the namesake of the horse, added a harness strap to their head and body and an early form of harness racing was born in the colonies. The organizers of the course set up regular meetings in spring and fall.

Horseracing and breeding found a home in colonial Maryland as well. In 1745, Governor Samuel Ogle introduced the first pedigreed thoroughbred horse races in Annapolis, Maryland. The Thoroughbred Owners and Breeders Association, in conjunction with The Blood Horse, published an article in 1942 entitled "An Introduction to the Thoroughbred Horse," that stated these early Maryland races began the thoroughbred racing and breeding in North America. Horsemen along the tidewater region founded the Maryland Jockey Club the same year. They founded the club based 
on the tradition of England's Jockey Club. Each spring and fall, Maryland towns such as Williamstadt, Annapolis, and Chestertown hosted races for trophy cups and purse money. Chestertown hosted a race in 1766 for the purse of fifty pistoles that brought together two of the most famous colonial horses of the time. The owners of Yorick, a seven-time starter from Virginia who won all seven races, and Selim, an undefeated Maryland thoroughbred, set up a match race over a grueling four-mile course. The affair drew hundreds of spectators from all along the coastal colonies. Selim proved too much that day and won by several lengths. 54 The 1752 sweepstakes race at Gloucester racecourse suggested an intense rivalry among the horsemen of Virginia and Maryland. Spectators, gamblers, owners, riders, and trainers across Virginia and Maryland made up the assemblage of racetrack attendees.

The popularity of the events spread to the Carolinas by the mid-eighteenth century. South Carolina horsemen established a jockey club by 1760 and they held regular race meets in Charleston by the same year. Like earlier Virginia horse importers and landowners, South Carolinians depended on English imported stock for the purposes of breeding and racing.

The colonists maintained the thoroughbred breed of horse and in 1730, the twenty one-year-old son of the Byerly Arabian, Bulle Rock, became the first true thoroughbred brought to America. While the landed gentry of the coastal colonies dominated the sport in early America, all walks of life and all classes of colonial citizens participated in the events. By the mid- to late-eighteenth century, thoroughbred racing in the tidewater colonies eclipsed the quarter horse meets in numbers and popularity. Thoroughbred racing tested the horse's speed over a longer distance. The races were usually run 
between a mile and a half and four miles on mile-long circular surfaces. These races became wildly popular among all classes of the colonial populace. In American Sports: From the Age of Folk Games to the Age of Televised Sports, Benjamin Radar argued that during this time period, "the colonial gentry apparently encouraged thoroughbred racing as a public spectacle" and that "men of all ranks attended their races." 55 By the start of the American Revolution, thoroughbred racing became the first organized sport in the colonies.

The colonial struggle for independence held back the horse fervor of the time. Northern colonists urged the extinction of horseracing as an extravagance not needed in such extreme times. Southern colonists, in what became their tradition, refused to amend or abolish horseracing in defiance of the aristocratic England, and, as some historians suggested, to spite the northern colonists. 56 Southern colonists claimed horseracing was a way of life for them. Only the need for horses and preparation for the war slowed the Southern uproar. An irony crept into horseracing legacy in America during the Revolution by way of the enemy. In September 1776, English citizens witnessed a horse race named in honor of a British army officer. The St. Leger race was an end-of-season sweepstakes race in England. The stipulation for this race was that the event was limited to three-year-old thoroughbred colts and fillies. Organizers of the race called the event "the Darby." Diomed, a swift three-year-old owned by Sir Charles Bunbury won the first English Darby. Two years later, Edward Stanley, twelfth Earl of Derby, recommended a race of the same nature, but for fillies only. He suggested the mile and a half race be named "The Oaks." The race was run in England for the first time in 1779. Ninety-six 
years later, the winner of the first Kentucky Derby, Aristides, was a blood-bred relative to Diomed. 57

By the time the Revolution concluded and as the turn of the nineteenth century approached, thoroughbred breeding in the newly formed United States had to start anew. Horseracing's popularity returned to post-Revolutionary America and enjoyed continued growth throughout the first decades of the nineteenth century. Colonel Hoomes, a Virginia horse breeder, bought Diomed and brought him to Virginia in 1799. Diomed was an enormous success as a sire in Virginia and remained so until 1806. The heart of the thoroughbred industry gradually moved from the tidewater regions of Virginia and Maryland to New York and the new southwestern states of Kentucky and Tennessee. Historian John Gilmer Speed noted that sectional divisions of races became popular in the first half of the nineteenth century. Speed argued, "Section against section soon became popular --- the North against the South, Virginia against South Carolina, Kentucky against Tennessee, and so on." 58 Speed detailed an 1823 sectional match held at Union Race Course in New York between the Southern bred Sir Henry and the Northern bred American Eclipse put on by the horsemen of Long Island for a purse of ten thousand dollars. He called the four mile heat race "the first, and in many regards the most important of these [sectional] contests." 59 By 1835, horseracing was highly organized with set racing agendas. The Union Race Course on Long Island, New York, for example, held crowds of nearly 50,000. At the same time, organizers of the track published advanced racing schedules, charged admissions, and published results in the daily newspapers. William Porter introduced his Spirit of the Times newssheet that informed racegoers of pertinent insights of the horse industry. The American Turf 
Register and Sporting Magazine, first published in 1829 by John S. Skinner of Baltimore, Maryland, was written by the racing enthusiast for the interest of increasing numbers of racing fans. 60

Several social and economic factors contributed to racing's popularity in the first half of the nineteenth century. A new demand for leisure time activities lay at the heart of the enormous resurgence of racing's popularity. The racetrack became the physical and recreational symbol for entrepreneurs who viewed horseracing as a way to make a profit. No sport in the first half of the nineteenth century offered this clientele such an organized event on a regular schedule than that of horseracing. Only the economic Panic of 1837 and the newly popular trotting races halted, albeit temporarily, the demand for racing during this period. Although social class standing determined prime participation for the races in ownership and seating, people of all classes flocked to the newly built tracks of the day.

Perhaps the best primary source document from that era that demonstrated horseracing's all-inclusive draw was the May 5, 1845 edition of the New York Herald. This edition described a match race - - - the most common form of racing at the time - - held at Union Race Course. The match pitted a southern mare, Peytona, against the northern mare, Fashion. Race organizers scheduled the two mares to run three heats of four miles each (unheard of today, but normal for the time). What was most telling about the event was the Herald's description of the crowd and circumstances that surrounded the race. The newspaper thundered, "the contest between the North and the South for the dominion of the turf was to be settled." 61 The article continued with a detailed description of the crowd and participants for the much-anticipated race. 
Long trains of carriages, filled with all sorts of people, reaching to Broadway, lined Whitehall Street. Here was the magnificent barouche of the millionaire, full of gay, laughing, dark-eyed demoiselles, jammed in between a Bowery stage and a Broadway hack ... we saw many distinguished sporting characters, politicians, editors, reporters, managers, actors, printers' devils, \&c., among the group.

On the arrival of the crowd at the track, the paper continued,

The passengers were set down immediately beside the course ... on the edge of which are a half dozen dwelling houses. These were all converted into dram shops and places of refreshment ... they had the honor of an early call from a large portion of the race-going blades, who, after their dusty and perilous journey, per railway, were ready for a grateful draught of something or other to wash down the dust.

The foremost inclusion in the article that highlighted this day as a day for the vast divisions in society was the following:

This passage (by the track) was about twenty yards wide ... it was occupied by all sorts of irregular forces, and indescribable camp followers, sutlers, loungers, rowdies, gamblers, and twenty other species of the genus loose fish ... The enclosed area, whose circumference of a mile formed the Course, as the resort of the carriates and the horsemen ... Immediately on the right of the Judge's stand, and the opposite to the great stand for spectators, on the other side of the course, a dense mass of vehicles of all descriptions congregated ... As may be expected, the occupants of them were of a more mixed class than those who lolled in the private carriages ... hundreds seated themselves on the grass, but by far the larger number went roaming up and down, seeking rest but finding none, until finding spirits more wicked than themselves, they entered into the swept and garnished groggery .... 62

Research suggests that 30,000 people attended the races that day. The Union Race Course became a microcosm of horse racing to that period in American history. To the Civil War, the country had never witnessed a sport, leisure, or recreational activity that included both the most humble working people to the highest elite of the day. The southern gentry came away victorious that day as their hearty handshakes of congratulations ushered home the speedy Peytona, winner of the first heat by two 
lengths. The third heat was not needed. Peytona shook free from Fashion in the backstretch of the second heat to win by a length. The winning time was seven minutes, forty-five and one-forth seconds. The southern mare had earned her well-attended victory.

The second half of the nineteenth century ushered in a distinct and energetic time in Unites States' horseracing history. The horsemen of the country made concerted efforts to organize, promote, and heighten the racing industry. In 1866, Leonard W. Jerome, William R. Travers, and August Belmont established the American Jockey Club. The eight hundred and twenty six-member club procured over two hundred acres of land and built Jerome Park, an extravagant racetrack that included such comforts as a dining room, clubhouse, and lodging. Sports historian Melvin L. Adelman called the formation of the club "a pivotal event in the history of American thoroughbred racing." 63 The members of the Jockey Club not only helped bring New York racing out of the economic troubles of mid-century, but they advanced enthusiasm for thoroughbred racing around the country. Encouraged by the Jerome Park example, supporters of horseracing oversaw other notable racetrack openings such as Monmouth Park in Oceanport, New Jersey and Pimlico Park in Baltimore, Maryland in 1870, and in 1875, Churchill Downs in Louisville, Kentucky. In addition, in 1873, horsemen Sanders D. Bruce published Volume One and Volume Two of the American Stud Book that advanced the record keeping of the growing industry. Because of the numerous errors discovered by horse researchers of the time, the newly formed Jockey Club bought the publication in 1896 and registered all American thoroughbreds in their books. The club provided information on uniform national racing rules, racing dates, and jockey licenses. Radar labeled this 
time period in racing as "the golden age of horse racing." 64 By the end of the century, thoroughbred horseracing had become a professional and business venture. By 1900, all walks of life and social classes participated at the different ownership, racing, breeding, gambling, and attendance levels of the thoroughbred industry.

While the popularity of thoroughbred racing was at an all time high at the beginning of the twentieth century, so too were the anti-gambling sentiments that set their sights on United States' racetracks. New York State was hit especially hard as state legislatures passed anti-gambling laws that led to closed tracks and bankrupt stables. On June 11, 1908, New York governor and future Supreme Court Chief Justice Charles Evans Hughes signed the Agnew-Perkins Bill that made New York racing directors liable for any betting on New York racetracks. Two years later, legislatures outlawed any verbal betting at the tracks and, further, blacked out racing in the state for the following two years. By the end of the first decade of the twentieth century, racetracks open for operation in the United States numbered in the twenties. 65 Matt Winn, Churchill Downs' vice-president and general manager at the time, re-introduced pari-mutuel wagering, not undertaken at the Kentucky Derby since 1887 . The pari-mutuel betting that Winn re-introduced at the 1908 Kentucky Derby stemmed the fervor of the antigambling sentiment. In 1878, Kentucky state legislatures passed a statute that enabled pari-mutuel, or the French pool, type of gambling that was exempt from the antigambling provisions in the law. Pari-mutuel is a term that means "among ourselves." In this form of betting, gamblers bet against each other and not a bookmaking house. Since no official bookmaker handling the bets existed on the grounds of Churchill Downs, the pari-mutuel betting was exempt from the 1878 legislation. No one engaged in actual 
bookmaking at Churchill Downs, as clerks staffed the eleven pari-mutuel machines on site. The sellers of the pari-mutuel ticket called in the numbers of wagers made. Operators of the Maryland tracks followed the lead of Winn and Churchill Downs and introduced pari-mutual wagering a few years later in 1912.

In 1976, Dean Alfange in, The Horse Racing Industry, examined horse racing from an industrial point of view. He claimed the horse racing was a "chimeric conglomerate of disparate elements." 66 He further wrote, "The world of racing is fragmented into numerous microcosms." 67 Alfange labeled the first half of twentieth century racing and its events, "The Resurrection." As horsemen like Winn ushered the racing business into the second decade of the twentieth century, the varied personalities of the sport came to the rescue of the ever-growing industry and, as Alfange wrote, resurrected its image.

The horsemen of New York revived racing at Belmont Park in 1913, Maryland's Bowie racetrack opened in 1914, and Churchill Downs' Kentucky Derby had weathered the anti-gambling movement and became one the premier races in the United States. When the United States became involved in the World War in 1917, at the urging of Winn, Churchill Downs pledged ten percent of the track's handle, employee's salaries, and horsemen's earnings to the Red Cross. When a potato shortage hit the United States, Winn turned the infield at Churchill Downs into a potato field, with all the profits earmarked to the Red Cross. By 1919, sportswriter Charles Hatton coined the phrase "Triple Crown" to the winner of racing's three major spring races - - - the Kentucky Derby, the Maryland Preakness, and the New York Belmont. 68 The Miami Jockey Club opened Hialeah Park in 1925 and Chicago horsemen oversaw the openings of 
Washington and Arlington Parks in 1926. Arlington Park included a tennis club and golf course on its property. The economic depression of the late twenties and thirties had no grave consequences on the viability of overall racing industry during the period. Minor financial effects rippled throughout the industry and individual tracks, but between 1929 and the start of the Second World War, twenty-four new racetracks opened for business, the most notable in 1934 at Santa Anita, California. By 1934, operators and managers at racetracks in California, Michigan, New Hampshire, New Mexico, North Carolina, Ohio, Oregon, Texas, Washington, and West Virginia authorized the use of pari-mutual betting. As the anti-gambling tide stemmed, the horse industry dealt with another potential danger, the coming of the Second World War. But the racetracks and the horse industry were mostly shielded from the toils of World War II, much as they survived World War I. While many track operations witnessed a decline in betting, racing survived and expanded during the turmoil of war. Executives of twenty-two racetracks met in 1942 at Chicago and established the Thoroughbred Racing Associations of the United States. Three years later, the association set up the Thoroughbred Racing Protective Bureau that coordinated the work of the racing industry during the war. Racetracks around the country set up war bond sales, and, by order of the federal government, closed all tracks from January through April of 1945. The federal government lifted the ban on May 9, 1945, but the racetrack's presidents and manager's cooperation gave the sport a glowing image throughout the country. By 1950 , racing was a major national industry and sport.

The second half of the twentieth century was a time of enormous regulation, association formation, legislation, and racing education throughout the industry. The industry blanketed the different types of racing - - - quarter horse, harness, and 
thoroughbred - - - under similar commissions and regulations. Off-track wagering became popular with the betting public and blossomed to a multi-billion dollar operation by the close of the century. Hundreds of thousands of spectators participated in racing events, wagering several million dollars. The horseracing industry became more complex and professionalized. Annual aggregate horse sales brought in millions of dollars for owners, breeders, and racing facilities. Some business schools added equine commerce classes to their curriculums as the business activity of the industry flourished. Enormous horse farms devoted to aspects of breeding, training, and health of the horse were commonplace throughout the horse-crazed states of Kentucky, Maryland, New York, and Virginia. The racing industry survived the crests and valleys of economic depression and war and became one of the most prevalent and enduring sporting triumphs up to the present day.

\section{The horse and horseracing in Kentucky}

From Daniel Boone's adventures in the Kentucky wilderness to the wildly popular "most famous two minutes in sports," the horse and horse industry constitutes a unique and vital component of Kentucky's economic and social history. From the earliest settlers of "the dark and bloody grounds" to Churchill Downs' backside regulars, horse and sport mingled together in Kentucky. 69 The horse played the role of travel companion and workmate to its present capacity as a potential economic windfall. Racetracks, stables, and horse farms opened around the state as racing enthusiasts continued their support of Kentucky's most popular industry, including the industries of tobacco, whiskey, and bourbon.

Social and institutional historians attributed various factors for the horse's 
popularity in Kentucky. How central Kentucky, in particular, became the focus of the horse racing and thoroughbred industry was unique. Kentucky historian Thomas Clark's

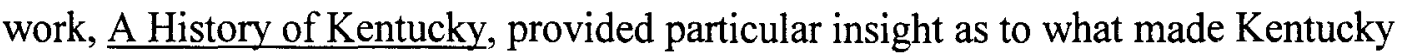
stand out from other states in the formation of horseracing and the thriving of the horse itself. Clark analyzed Kentucky's history of social institutions down to its simplest form of survival on the land and the land provisions as sustaining civilization. Clark claimed Kentucky's land "created sharp delineations in agrarian economy" and the "soils in the Bluegrass ... were conducive to the development of a profitable field crop and livestock economy." $70 \mathrm{He}$ stated that centuries before any Europeans inhabited or explored the Bluegrass, several species of livestock "roamed through the savannah lands and cane breaks of central Kentucky to fatten on the luxuriant growth of grasses and canes." 71 From the outset of his work, he noted those wild animals such as buffalo, deer, elk, and bear thrived on the land of Kentucky. Horse breeding and the industry tied to it were a natural for the state. What availed the horse to the Kentucky Bluegrass region more than any circumstance or event was the bluegrass specie of grass itself. The grass that became the namesake of the state had as much to do with the horse dominating the landscape as Boone or settlers from England and Virginia ever did. The deeply rooted, thin-bladed grass was unequaled in nurturing pedigreed horses. Agriculturists credited William Penn and the Mennonites of Russia with the introduction of the seed, native to the steppe regions of the Black Sea. When the Mennonites and other Pennsylvanians headed west for new lands and fertile pastures, they cleared lands in central Kentucky regions, of which Lexington was a part, and planted the Kentucky bluegrass. 
The horse found its way to the fertile Kentucky bluegrass regions by way of settlers and explorers, namely Daniel Boone and other hunters and explorers. Boone's party brought their horses for transportation and packing, then noticed how their horses "thrived in this new grazing land." 72 The hunters and surveyors returned to their eastern homes with stories of how material wealth could be extracted from the lands through the grazing advantages found in the West. 73 The actual start of the livestock industry in Kentucky occurred when the settlers from the eastern states brought large herds of domestic animals to the Boonesborough and Harrodsburg encampments set up in the 1770's. Among the many livestock were hundreds of horses. Boone acted as a delegate to the Transylvania Convention at Harrodsburg in 1775 when he introduced a bill aimed at improving the breed of horses in the western Virginia territory. This exploration into central Kentucky, then the westernmost county of Virginia, at the dawn of the American Revolution was the beginning of a decade long trek for Virginians. They brought their fondness for horses with them.

On August 11, 1787, when Kentucky was little more than wilderness, John and Fielding Bradford printed the first newspaper of the territory, the Kentucke Gazette. It carried advertisements in 1788 for six thoroughbred stallions who stood in stud. The advertisements were for the stud services in trade for tobacco or corn. 74 The paper published an advertisement for a pure thoroughbred stallion in April 1788. 75 The first evidence of a Virginia horse affecting the Kentucky stock occurred in the last decade of the eighteenth century. The first English thoroughbred in Kentucky was Blaze, imported to Virginia by General Hugh Nelson in 1793 and later purchased by Benjamin Wharton of Scott County, Kentucky. In addition, Sir Charles Bunbury sent the winner of the first 
English Darby, Diomed, to stud in England soon after his 1780 win. His sires mildly succeeded in English racing circles but, according to his English handlers, Diomed's useful days were behind him. 76 The English horse merchants considered him ineffectual and shipped him to Virginia in 1800 . His luck changed in the Virginia heartland and his sires in the United States grew to championship status. As the nineteenth century arrived, the blood relatives of the English champion appeared in the Bluegrass.

The War of 1812 shut down racing in the North and Northeast regions of the United States. Yet Kentucky's location, and particularly Lexington, was shielded from the harshness of war. Owners of horses and horsemen from the Atlantic and northern states discovered that no specie of grass was more comparable to the bluegrass.

Horsemen from around the country relocated to Kentucky and its undamaged pastures. Settlers found that central Kentucky was the best-pastured land available for their grazing cattle, sheep, and horses. The present-day counties of Fayette, Jessamine, Woodford, and Bourbon counties contained the most fertile soil that produced the soft cushioned turf, as well as an abundant food source for livestock.

Another impetus in Kentucky's equine emergence was the immigration of the horse and horsemen from the eastern seaboard. This "more complex type of society," as Clark referred to them, brought their love of horses to the Bluegrass. 77 Pinning down the exact date of the first race in Kentucky was impossible, but the new residents of Kentucky started the industry in their new homeland. The prevalent factors of the east coast element found a new and welcomed residence in Kentucky. In 1787, some of the first horse enthusiasts in Kentucky set up the first known informal racing track in 
Kentucky's on Race Street in Lexington. In the first two decades of the nineteenth century, settlers in Louisville established the Elmtree Garden racecourses on Shippingsport Island, the Hope Distillery course in Portland, and the Beargrass track in the southeastern part of Jefferson County where present day Taylorsville Road and Hurstbourne lane intersect. 78

In 1826 , sixty prominent citizens in Kentucky organized the Kentucky Association for the Improvements of Breeds and Stocks. These sixty Kentucky businessmen began the origins of written record keeping and breed registry in the industry. In 1868, their work led a horseman and Lexingtonian, Colonel Sanders D. Bruce, to create the American Stud Book. This registry was more efficient and organized than any recordings before it. In addition, in 1830 the first volume of the American Turf Register listed seven thoroughbreds who stood in Kentucky. By the end of the decade, that number had quadrupled.

The breeding and training of horses became big business in Kentucky by midcentury. Political and economic influences crept into the sport, as the rules and regulations of the industry materialized. By 1850 , America sang Stephen Foster's ode to the life and joys of racing, "Camptown Races." His ditty of long races, gambling, and bay horses suggested that horseracing was popular enough, especially in Foster's Kentucky, for integration in popular song. By 1875 , Louisville civic leaders, led by the Churchill family, opened The Louisville Jockey Club and Driving Park Association, now the present day Churchill Downs. In 1883, Kenton County businessmen bought a one hundred twenty-acre tract of land from Colonel James Taylor and built a one-mile track 
on the grounds. They named their course Latonia after a nearby resort, Lettonian Springs.

The horse industry in Kentucky and, in particular horseracing, mirrored the conditions of other recreational sporting activities throughout the twentieth century. Horseracing exploded in Kentucky by the beginning of the twentieth century and continued an upward climb to its present day levels. Turfway Park operated in Northern Kentucky, Ellis Park in Henderson, The Red Mile Harness Track in Lexington, and, of course, Churchill Downs in Louisville. Expanded races, wealthy purses, and simulcast broadcasting thrust horse racing in Kentucky to a previously unforeseen stature. But for racing enthusiasts and historians, the unique idea of a model track and racing ground became the unrivaled story in Kentucky's racing history. The history and story of racing in Lexington, particularly at Keeneland, was a rare event in the immense opus of Kentucky horse and racing history. It is a history that has remained largely an untold story.

\section{Lexington's Horse and Racing Traditions}

In The History of Pioneer Lexington: 1779-1806, Charles R. Staples wrote of Lexington as "the first metropolis of the Western Country." 79 John D. Wright, Jr., in his Lexington: Heart of the Bluegrass, claimed early Lexington as the "Eden of the West ... that a mythical quality about the region began to emerge." 80 Like descriptions became prevalent throughout the research on Lexington. No region in the United States claimed the favor that the Bluegrass Region did, with Lexington as its center, for the breeding and rearing of thoroughbred horses. The horse enthusiasts of central Kentucky were 
unrivaled throughout the United States in their thirst for racing, breeding, and improvement of the horse and horse industry.

Little historical research has been published on Lexington's horse and racing industries. Historians have included the research on the horse and racing traditions in Lexington as part of larger, more general works on the history of Kentucky horseracing, Fayette County, and/or Lexington. No definitive historical scholarship on the story of Lexington's horseracing heritage exists. For example, The Horse World of the Bluegrass was a handy work on the basic facts of Lexington's horse history. Edited by Bruce F. Denbo, with Mary E. Wharton and Edward L. Bowen, they limited their research and the book contained more feel-good material, rather than useful secondary historical content. Books like Denbo's defined the secondary literature on Lexington, its racing genesis, and the importance of the industry to the citizens of the Bluegrass Region of Kentucky. Horse enthusiasts wrote on the horse farms of the region, but mostly contained information on horses sired or pedigrees of horses kept at the farms. Much historical research was yet to be done on the finest region in the country for the thoroughbred industry.

The settlers of Virginia brought their passion for horses and racing with them and central Kentucky became the core of their fondness. Citizens of Lexington set up the first racing paths in 1780 and officially recorded races in Lexington as early as 1787 , five years before Kentucky was admitted to the United States as the fifteenth state. From May to September 1787, while fifty-five of the country's elite gathered in Philadelphia composing the course of the new nation's government, Lexington residents gathered to discuss the speed and maneuverability of their horses. Main Street became the first 
known venue for racing in Lexington. Racing horses through the streets became the manner in which owners and onlookers settled clashes and wagers relevant to their, or someone else's, horse. They used the streets around the inns and taverns to settle their disputes. Horse owners and gamblers used Lexington's Main Street, where a number of inns and taverns opened for business, as the first informal racecourse. These inns and taverns of Lexington provided rooms for gambling, card games, and billiards.

Lexingtonian James Bray opened a tavern around 1786 on Main Street between Main Cross and Spring streets and by 1787, John McNair opened his "The Sign of the Buffalo" on Main Street. John Higbee opened a tavern on the corner of Mulberry (Limestone) and High streets that provided another outlet for the city's horsemen to argue the merits of a horse. No sport or gambling activity reached the spirit of Lexington's citizens like horseracing. While the owners bragged and discussed bloodlines, gaits, and colors, only one way existed to determine which owner claimed the fastest horse - - - racing. Some citizens of Lexington became uneasy at the "jockeys racing their horses through the streets" and appealed to the newly appointed trustees to hold an election to stop the practice. 81 The majority favored the banning of racing through any street for the fear of flying hooves and its danger to humans. The trustees issued an order that confined the races to the "lower end of the Commons where stud horses can be shown." 82

Racing then moved along Race and Main streets as Lexington horsemen ushered in their horseracing legacy at the impasse of what are now downtown Lexington's city streets. These street races served as the beginning of what became Lexington's, and all of Kentucky's, claim to fame. By the beginning of 1788, settlers of Lexington developed 
a robust horse-friendly community. The tax books in Lexington for 1788 revealed 2466 horses in the city. One year later, the total was 9607 , as well as fifty-six stallions. 83 The horses raced across obstacles and finished at the edge of Lexington's woodlands. The Kentucke Gazzette printed an advertisement in 1789 for a purse race in October of that year for a "best of 2 in 3" of three-mile heats and that "the rules of New Market" applied, a deference paid by the organizers of the race to the established track in England. 84 Showing horses became popular as well. On March 16, 1795, the trustees of Lexington made part of Water Street an apportionment for showing stud horses for sale.

85 The Gazette continued advertising races and the first article on racing events appeared in the paper on November 12, 1795. This article included information on a four-mile heat with three horses, won by Colonel Simeon Buford's Mogul, and a five horse, threemile heat won by Abraham Buford's Weazel.

The first formal racetrack ever constructed in Lexington opened in 1797 at Old Williams Track in Lee's Woods on the north end of West Main Street, now part of the Lexington Cemetery. Horseracing developed such a following in Lexington that elite horsemen formed a Jockey Club in 1797, modeled after the traditional English clubs. The most influential of the Lexington horsemen met at the corner of Main and Mulberry (Limestone) streets at John Postlethwait's tavern, later the Phoenix Hotel, and organized the Kentucky Jockey Club on October 17, 1797. An examination of the resolutions of the club revealed that the members established, for the first time in Kentucky's history, rules for horse racing. 86 The attendees adopted three resolutions that October day. First, was the resolution that regarded days of racing and the distance run. Secondly, the attendees established a five-person committee "to admit persons wishing to become members of the 
club." 87 Finally, the attendees resolved to meet again at the same venue one week later. 88 The Kentucky Jockey Club members changed their name to the Lexington Jockey Club in 1809 and boasted Henry Clay as a founding member. At the turn of the nineteenth century, Clay held races and thoroughbred horse shows at his home, the Ashland Estate. Lexington race enthusiasts organized races on any avenue large and wide enough to hold the horses. Owners of the horses raced on the merits of their egos and over who had the sturdiest and fastest horse.

The horsemen of Lexington wanted to broaden the specter of racing and, in 1826, changed the Jockey Club to the Kentucky Association for the Improvement of the Breeds of Stock. The horse community of Lexington became interested in the quality of breeding of horses in the Bluegrass Region. The biggest improvement made by the Kentucky Association for the horsemen were rewards through racing. Racing at Lee's Woods until 1828, the members of the Association decided to build a dirt track modeled after the Union Course in New York. The members decided to make an oval-shaped track a few years after its opening and the Kentucky Association track became only the second enclosed track in the United States. Racing continued at this track, located at Fifth and Race streets, until its closing in 1933. Members of the Association became involved in sponsoring fairs in Lexington and, coupled with the Kentucky Agricultural and Mechanical Society, established races at the Fair Grounds until the late 1876. The society purchased the Fair Grounds acreage that ran adjacent to present day Euclid Avenue, Limestone, and Rose Streets. The Agricultural and Mechanical Society sold the land for use as a city park in 1876 and purchased a sixty-two acre tract of land on South Broadway. The members of the Agricultural and Mechanical Society had a grandstand, 
racecourse, and floral hall built which still stands today as part of the Red Mile harness racing track, home of the Kentucky Futurity, the oldest American stakes race for harness racing. The Kentucky Association supervised racing in Lexington for over a century. 89 The Depression of the 1920's and 1930's took its toll on the lone racing venue in Lexington as horses and the wagers placed on them took a hard back seat to food and mere survival. The Kentucky Association racetrack was the oldest racetrack in the United States by this time. With the track's crumbling condition, members of the Association concluded that renovation was too massive a job and too expensive during the economically harsh period. The Kentucky Association hosted its last meeting in 1933. For the first time in its history, Lexington horseracing came to a halt and, for the first time in over a century, Lexington found itself without an official horseracing venue.

Horseracing formed on of the roots of United States sport and recreation heritage. It was the oldest and most organized sport in the colonies as the English settlers brought their love of the horse and horseracing with them. The beginning of organized horseracing began in the tidewater colonies of Maryland, Virginia, New York, and the Carolinas. As the popularity of horseracing grew in the United States, Kentucky became the center of the growing thoroughbred industry. The horsemen of central Kentucky, particularly Lexington, were unrivaled in their desire for the improvement of the horse industry. In 1933, the oldest racetrack in the United States was located in Lexington, Kentucky. Its operators closed the track the same year and Lexington, in the heart of the thoroughbred racing industry, was without an official racing venue for the first time in the city's history. Chapter Two examines the unique formation of Keeneland racecourse and the equally unique association of men that oversaw its founding. 


\section{CHAPTER TWO \\ THE IDEA OF KEENELAND: PURE BLUEGRASS}

Keeneland's opening by a group of forward-thinking Lexington horsemen was a most unique act in United States horseracing history. "In short, this is to be a model track, for sport alone, to be conducted by the sons and grandsons of sportsmen ... established here by their forebears" was how the premier magazine in the horse industry, The Blood Horse, described Keeneland in 1935, almost a year before its completion. 1 The horsemen of Lexington designed and created Keeneland as a model racing, breeding, and training plant unlike any facility in the United States. The opening paragraph of Keeneland's 2002 annual media guide stated that Keeneland was designed as "a track that would cultivate an enduring appreciation and respect for the noble sport of horse racing." 2 History student and writer Ann Sims argued in her 1941 article that Keeneland "stands as a monument to the thoroughbred horse ... the finest horsemen in America gather to witness the finest races at the only track in America where racing is designed for the sheer sport of it." 3 But the most enduring component of Keeneland was the desire of the horsemen to open the track on a non-profit basis. No group in United States horseracing history had ever attempted to open a racetrack in the style of Keeneland. Not only did the association of horsemen want a racing venue, but they also desired a physical plant devoted to the training, breeding, and betterment of the thoroughbred horse. The operators of Keeneland continue that desire today. 
This chapter explores the formation of Keeneland and the extraordinary men who organized the financial backing behind the project. The association's meetings, the formal and informal documentation they created, and their production of the most unique thoroughbred racing plant in the United States are discussed in the chapter. Lexington horsemen John Oliver Keene's role and history in the horse industry is detailed in this chapter as well. Without Keene's fate during the depression of the 1930's, the history of Keeneland would have been significantly altered. The chapter concludes with the examination of Keeneland Association's opening of Keeneland in October 1936.

Little historical research has been published by sports, horse, and racing historians on the founding of Keeneland. Much like feel-good books on the Kentucky Derby, the scholarship on Keeneland has been overly general and targeted for collector types. Beyond glorifying the beauty of Keeneland, few commentators have written useful historical research on the men or motives behind the opening of Keeneland. In addition, historians have published almost nothing on the weekly odyssey the association of men labored over as they tried to bring racing back to Lexington. The remarkable story of Keeneland lay in the association and their meetings from January through August 1935. That hardly any scholarship by sport and recreation historians was written on the organization was difficult to reconcile, given the enormous material elsewhere on United States horse and horse racing history.

In 1960, J.B Faulconer wrote, The Keeneland Story: A Quarter-Century of Racing in the Finest Tradition, which was one of the most useful secondary source materials for researches of Keeneland. But most of the work in the secondary area was the collective, coffee table variety. For example, in 1991, Nancy Stout wrote, Great American 
Thoroughbred Race Tracks, but only included a thirteen-page article about Keeneland. In 1938, two years after Keeneland opened, Elizabeth Simpson published The Enchanted Bluegrass that included a scant six-page chapter on Keeneland. The lack of this material directed the research to the primary periodicals and documents, which mainly consisted of The Thoroughbred Record, The Blood Horse, and Keeneland's own publication, Keeneland Magazine. The lack of publications and research in the secondary area about the formation of Keeneland was frustrating. The horsemen's establishment of Keeneland was a unique episode in American sports history and one of horseracing's incomparable stories. That no succinct literature has been published about the genesis of Keeneland, as well as the unconventional nature of its purpose, was surprising. Keeneland's story is one worth telling.

The horsemen of Lexington desired a place to breed, race, and improve the stock of thoroughbreds and from this desire was born Keeneland. With the closing of Lexington's Kentucky Association track in 1933, horse enthusiasts in Lexington were without an official racing venue for the first time in over a century. Racing had come to a halt since the first races in Lexington along Main Street. By 1933, the Kentucky Association was in disrepair and its operators had little choice but to close the track. The oldest racetrack in the United States at the time was no longer a part of Lexington, but the desire of its horsemen for racing, breeding, and training thoroughbreds was. The horse supporters could not stand that their city was without an organization or association that had a major role in the thoroughbred industry. The prestige, the ambiance, and the feel of the sport of kings were gone. As the end of 1934 arrived, so, too, did the prospects for racing in Lexington. Without the guidance, desire, and diligence of a few horsemen of 
Lexington at the beginning of 1935 , the future of racing in the Bluegrass Region would have been markedly different. In addition, the history of Keeneland and the thoroughbred industry would have been dramatically different if it were not for the economic hardships of John Oliver Keene.

John Oliver Keene was born into the horse industry. Keene, known by his friends since his schoolboy days as Jack, grew up in the heart of the Bluegrass in Fayette County and Lexington. He spent his childhood days meandering Keeneland Farm just outside Lexington's city limits. The farm, of which he would later own, was the ancestral home of his parents. Near the end of the eighteenth century, then-Virginia governor Patrick Henry gave the Keene family the farmland. Henry granted horsemen Francis Keene nearly eight thousand acres of land in the heart of the Bluegrass Region that became known to Lexingtonians as the "Old Keene Place." 4 In 1790, Keene completed construction of the main house on the property. Generations of Keenes lived and died at the residence and, until the sale of the house in 1935 to the Keeneland Association, no one ever owned the house other than someone in the Keene family. 5

The Keene names of Foxhall, John O.'s father, and James Robert, John O.'s grandfather, were steeped in the horse and racing traditions in places such as Kentucky, California, and New York. They passed down to their relatives their knowledge of horses and breeding that eventually reached Jack. At the turn of the twentieth century and his schooldays over, Jack moved to Illinois and worked for a Chicago horse firm as a handler of general horse breeds. Having grown up in the heart of thoroughbred country, Keene had a natural fondness for horses. His early years at the Kentucky Association track taught him a great deal about the handling and racing of horses. While in Chicago, 
Keene met prominent Chicago sportsmen Charles Head Smith. Smith operated several stables at the local tracks and, a short time after their meeting, appointed Keene to a position in his business. But Keene grew tired of laboring in stalls and stables and wanted to try his hand as an owner and trainer of thoroughbreds. In Chicago, Keene purchased his first horse, Braw Lad, that won numerous and generous purses on the local racing circuit. He began to manage his own stables and called his brother Ham to assist him. Keene branched out to the West Coast and tried the San Francisco racing circuit and, while in California, met Canadian sportsmen Jimmy Fletcher. Fletcher had a plan to travel the world and bring American horses, most notably those in Keene's stables, to race and advance the horse industry outside the United States. Keene saw an opportunity in Fletcher's idea and, by the end of the first decade of the twentieth century, the two went off to travel abroad. 6

Keene and Fletcher sailed to Japan from the West Coast and heard tales of racing in Tokyo from the Japanese horsemen. They visited the Japanese tracks that convinced Keene the horses in his San Francisco stables could earn a hefty sum of Japanese racing money. Jack cabled his brother Ham with orders to send his horses, a groom, and a rider to Tokyo. He was correct in his intuition about his horses. He and Fletcher entered the horses in the Tokyo races and built a large bankroll from the purses and wagers. A prominent Japanese businessman took an interest in Keene and Fletcher and inquired about the stable of horses they had shipped from California. The men struck a deal and the horses were sold. Keene and Fletcher arranged that the groom and rider be shipped back to San Francisco, while they made plans to travel from Japan to Russia. 
When Keene and Fletcher arrived in Russia, they accepted a Russian nobleman's proposal to train an entire stable of horses. But Keene longed for the Bluegrass and his homeland. After nearly three years of prosperity that followed their union, he returned to Lexington. Keene wanted to put to work at his farm all he had learned about thoroughbred horses. After his return, Keene received a cablegram from the nobleman's wife urging him to return to the training and managing job in Russia. Keene nearly accepted her offer. The 1917 Bolshevik takeover scared Keene into staying in Lexington. The bluegrass had the communist revolution to thank for keeping one of its greatest horsemen at home! 7

Keene returned from abroad to Kentucky where, in 1916, he began constructing his vision of a farm and training grounds that would raise the level of the thoroughbred horse higher than anywhere he had traveled. He began the process of building a track, barns, stables, and clubhouse that would be unlike any facility in the United States. The tract of land he built on was on the Keene family land located six miles from Lexington's city limits on the Versailles Pike, boundaries that have since passed with the merger of Fayette County and the city of Lexington. Using the limestone quarries on his land, Keene began construction of his racing plant of buildings that also included living quarters. He named his project Keeneland Stud. While the Keene family name was synonymous with thoroughbreds, it was not until the beginning of the twentieth century when Keene began raising a stable of horses for breeding and racing that the Keene farm became famous. His dream was to build a track for friends and horse lovers to come and watch their horses run. Keene wanted a model racing facility used for the advancement of the horse industry as well as improving the breed of thoroughbred stock in Kentucky 
and the United States. The track was of high quality and Keene supervised most the construction personally. But the depression of the 1930's hindered Keene's plans. The economic difficulties, coupled with the closing of the Kentucky Association track, halted the major avenues for the racing industry in Lexington. While the surrounding horse farms of the region continued to produce thoroughbred breeds, the Association closing and Keene's economic obstacles hindered the thoroughbred industry in central Kentucky.

Lexington's horse industry had declined by the start of the 1930s. The Kentucky Association lasted only three more years and Keene's plans for a thoroughbred haven came to a halt. By the mid-1930s, the Lexington horse community was distraught and concerned about the condition of their most famous industry. While the rest of the country faced the brutal conditions of the depression, Lexington citizens were figuring out how to bring horseracing back to their city. The first order of business for the community was dealing with the defunct Kentucky Association track and its capital.

During the first week of 1935, the retired president of the Kentucky Association, S. Sewell Combs, held a meeting in Lexington with the preferred stockholders of the track. Horsemen Johnson M. Camden, Maurice L. Galvin, and Arthur B. (A. B.) Hancock represented the American Turf Association at the meeting, while Thomas Piatt, Victor Dodge, and Samuel Yantis represented the Kentucky Association's preferred stock and bondholders. The groups discussed the final financial settlement of the Association track. Their purpose for the meeting was to discuss the distribution of the shares of common stock and notes of the Kentucky Association to its investors and operators. Combs was in charge of overseeing delivery of 1900 shares of stock and $\$ 39,000$ of combined stock and notes, held in escrow at the First National Bank and Trust Company 
of Lexington, to ninety-five preferred stock and bondholders. In addition, the attendees discussed disseminating leftover funds and $\$ 4100$ owed to the track's secretary, Miss M. Louise Wilson. But the horseman of Lexington knew there was a larger, more pressing reason they were at the hotel. 8 The topic was discussed as soon as the meeting started: how to revive racing in Lexington. Editors of the Blood Horse wrote that the meeting was "sounding the sentiment of the people of Lexington and vicinity as to what may best be done and how best to proceed in discharging this obligation [of the Kentucky Association] and in reviving racing in Lexington. The committee is finding a healthy sentiment for revival of racing ...." 9

Since the close of their last racetrack, Lexingtonians "generally felt the loss of the [race] meetings, and they appear also to be feeling keenly the loss to Lexington of the prestige it formerly enjoyed ...." 10 Lexington's thoroughbred owners and breeders wanted to sell the old Association plant and start a new facility beyond the city limits. That the oldest surviving racetrack in the United States was no longer open was unacceptable to the committee and to the horse community of Lexington. What defined their city was gone and the citizens refused to accept the notion of having no venue for the thoroughbred industry in Lexington. By this time, Jack Keene had already proposed to the Association a deed for nearly one hundred acres of his farmland. The horsemen's frustration and Keene's economic troubles came together in the following weeks.

On February 16, 1935 a group of prominent horsemen held the first substantive meeting at the Thoroughbred Club of America's meeting in Lexington's Phoenix Hotel (on the site of the old Postlewaite's Tavern) that focused on bringing a racing venue back to Lexington. Thomas P. Cromwell, editor of The Blood Horse magazine, served as the 
spokesman for the meeting. An assemblage of horseman made up of Piatt, Yantis, and Dodge, along with Lexington sportsmen Major Louie Beard and Jack S. Young, presented to the Thoroughbred Club a "prospectus for perpetuation of racing at Lexington, Kentucky ...."11 With the presentation of this prospectus, the group commenced plans for the most unique venue for horseracing that had ever been contrived in the United States. Cromwell read the plans that provided for "a racing ground and horse activities center at Lexington," as well as an association of the horsemen completely "unaffiliated with and not subservient to any other racing association" in America. Further, the prospectus stated that the association members in Lexington "shall be agreeable to its non-profit feature." 12 The committee's plans were monumental and distinct in the horseracing industry. At no other time in United States horse or racing history had any group submitted such an unusual idea. The members of the Thoroughbred Club were ecstatic with the prospectus and their members volunteered to take copies of the proposal for distribution to the citizens of Lexington. 13

On Friday, March 1, 1935, Louie Beard anchored a meeting of the Lexington Optimist Club in Lexington's Lafayette Hotel. The attendance at the meeting was double its normal size. The excitement the prospectus caused around Lexington, as well as the announcement by the committee that they would give their first public statements on the status of the plan, was the reason for the heightened attendance. 14 Beard told the horsemen of the plan to retire the debt of the Kentucky Association's bondholders and of the idea for a new racetrack in Lexington. He pronounced that the idea was to build a new track "from the ground up" and that several sites were being considered for the project. 15 One site was the large Upshar Berryman property, on the back of a settlement 
called Warrentown, between the Paris and Russell Cave Pikes. Other sites considered by the committee were an abandoned aviation field on Leestown Pike, an area of land on Clay's Mill Pike, and a family property on South Broadway. But one of the more engaging sites was the farm off the Versailles Pike known as Keeneland Stud. Jack Keene's land already contained a mile and a furlong track, an inner turf track, and a stone barn. Keene had already spent nearly $\$ 400,000$ and twenty years in building the tracks and barn. He wanted to build a facility for the betterment of the thoroughbred horse through training and breeding.

It was at the March 1 meeting that the committee began to reveal the unique aspects of the financial package to finance and build a new racing plant. Beard claimed that it was the desire of the committee "that every penny of the capital needed will be subscribed by property owners in the Blue Grass." In addition, "there will be no profit ... the remainder of the track's income ... will be devoted to a perpetual stakes fund and ... improvements for the track and retirement of the stock." 16 Beard's announcement was phenomenal. At a time when the United States was dealing with the harshest economic depression in its history, horsemen of Kentucky moved forward with plans to open a racing venue on a non-profit basis. The major order of business left for the committee was to decide on a location.

On Tuesday, March 12, 1935, the self-appointed committee met again at the Phoenix Hotel in Lexington. Major Beard presented to the attendees four sites the committee considered in the vicinity for the new racetrack. Beard centered his discussion on Keene's quaint tract of land and half-finished facilities. According to Beard and the committee's research on the proposed sites, the complete cost for opening a track on the 
Keene farm ready for racing was $\$ 350,000$. The deal for that amount included nearly one-hundred-fifty acres in the southwest corner of the estate with equal frontage along Versailles and Rice Pikes. Included with the land was Keene's private track he had constructed four years earlier. In addition, Keene included a stone building, a barn he had worked on for over twenty years, and a 100,000-gallon water tank he used to supply the farm. He also included enough land on the south, west, and north side of the track for stables and parking lots. By agreeing to the deal for his land, Keene envisioned a method to continue his dream of providing a thoroughbred sanctuary on his farm in Lexington. The deal was perfect for both he and the horse enthusiasts in Lexington and central Kentucky. Meshing Keene's idea while reviving racing created the genesis for the model racing plant of Keeneland.

The Keeneland idea advanced rapidly among the members of the association. On Wednesday, March 20, 1935, Jack S. Young presided over a meeting of over two hundred of central Kentucky and Lexington's sportsmen. The Lafayette Hotel in Lexington hosted the meeting and as became custom, Major Beard did most of the speaking. Beard's first order of business was to dispel rumors circulated by horse interests throughout the bluegrass that financing for the new racetrack would, in part, come from sources outside Kentucky. Major Beard emphatically stated that no such financing would take place, nor would there ever be any plans for such financing. His brief talk assured the sportsmen in attendance that the track's financing would come from Kentuckians, horsemen of Kentucky, and citizens from the Bluegrass only. He concluded his discussion by denying rumors that he was to be appointed by members of the informal committee as president of a newly formed association, the Keeneland 
Association. Later in the meeting, Young announced that approval of the men was needed for the appointments to the new association. The attendees unanimously approved the formation and its leadership structure. The committee appointed Lexington horseman Hal Price Headly chairman of the group. Finally, Beard announced the new track and clubhouse would be completed and ready for racing by the fall of 1936 and that the track was going to be "the like of which you will not find anywhere in the world." 17

On April 17, 1935, the Keeneland Association, with newly approved Headley as its chairman, filed articles of incorporation that provided for the most unusual financial package ever written for a racetrack in the United States. The articles were straightforward and the financial plan called for the raising of $\$ 350,000$. The committee proposed raising money for the expenditures by selling shares of preferred stock for one hundred dollars. For each share of preferred stock bought by investors, the organization would give the buyer one share of common stock. The Association offered 3500 shares of preferred stock and 3500 shares of common stock. The general purpose for the Keeneland Association was also included in the articles and stated that conducting horse shows, fairs, race meetings, and horse sales were to be Keeneland's main functions. In addition, the articles provided that, in conjunction with the shows, sales, and races, Keeneland operators were "to conduct any other business, whether herein specifically enumerated or not, which in the opinion of the board of directors of the corporation will improve the breeding of livestock of any kind." 18

Numerous facets to the plan existed that were different from any racetrack facility ever opened in the United States, either before or after Keeneland. For example, the association wanted only investors from Kentucky and included a provision in the articles 
that all officers and directors of Keeneland be native Kentuckians. The common stock would be voting stock only and have no monetary value. In addition, the organization wanted the common stock to be non-transferable to safeguard against parties who may only have, in the future, a financial interest in the track. Furthermore, according to the charter, Keeneland could pay no salaries to anyone except for a secretary, a track superintendent and daily workers, such as mutuel clerks and laborers. By the beginning of June 1935, the Federal Securities Commission granted permission for the Association to start soliciting subscriptions for stock. At the beginning of June, Headley and Wallace Muir, attorney for the Association, announced the Association's drive to sell stock would begin on Monday, June 17. It was the Association's intention to retire the stock as quickly as profits permitted. All revenue thereafter was to be used for improvements to the facilities and purses for the races, including higher stakes races. The Association agreed that if $\$ 225,000$ of the amount was not raised by August 15,1935 , they would abandon their plans and "the Blue Grass will continue to be without a show window for the product that has made Kentucky famous the world over." 19

On the evening of June 17, Headley hosted an organizational meeting of the Keeneland Association at his home, Beaumont. That evening, the assembled members passed a resolution giving Judge Richard B. Stoll permission to draw up agreement papers stating that the voting trust must keep the Keeneland Association as a non-profit project, "devoted solely to the good of the sport and the good of the community." 20 On the evening of the first night of the financial drive to purchase the land for Keeneland, the members of the Association, instead of worrying over finances, ensured their general mission for Keeneland remained at the heart of the project. 
Throughout the summer of 1935 , the stock subscription drive raised money and by mid-August, it was apparent to the Association that they had reached their financial goals. On August 29, 1935, the Keeneland Association purchased one hundred and forty seven and a half acres of land from Jack Keene for $\$ 130,000$ and $\$ 10,000$ dollars in preferred stock. The horsemen of Kentucky no longer had to talk about their dream. All they had to do at this point was oversee the construction of the finest and most noteworthy racing venue in the United States. The Keeneland Association anticipated its opening of Keeneland racetrack on October 15, 1936.

Racing in Lexington and the prestige it brought to its citizens was on its way back. The Association scheduled the opening meet at Keeneland for fall 1936 that included racing on nine days, beginning Thursday, October 15, and finishing on Saturday, October 24. On October 11, Keeneland Association members hosted an open house at the track that more than fifteen thousand people attended. Keeneland's race managers scheduled seven races each day except days when stakes races were to be ran. The stakes races for the meets were the Keen Stakes on opening day, followed by the Ashland, Breeder's, and Lexington Stakes. Keeneland's race managers organized some unusual pre-race conditions for the first meet as well. Track operators had never attempted these conditions before. For example, track secretary Charles McLennan announced a $\$ 1000$ "Owner's Handicap" race on the schedule allowing owners entering their horses to assign their own weights. The operators also scheduled a $\$ 1200$ race, the "Roll Your Own Handicap," that allowed owners to enter their horses only if they belonged to a breeding farm in Kentucky. 
Opening day at Keeneland was a perfect day, with attendance of nearly eight thousand people. On Saturday, October 17, 1936, the editors of The Thoroughbred

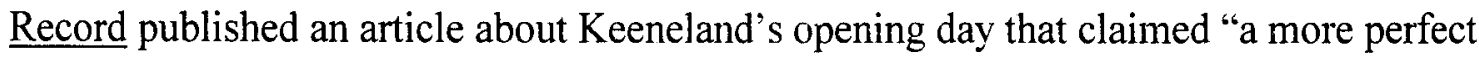
day or more ideal surroundings for the sport can scarcely be imagined." 21 On October 15, opening day at Keeneland, the publishers of The Lexington Leader included an article on the front page that called Keeneland's opening day "cause for rejoicing ... where the matching of thoroughbred horseflesh has been an important part of everyday life since the first settlers cleared away enough Indians and trees to have a Main street on which to run their horses." 22 When the bugle player called eight thoroughbreds to the post for the first race, "there was almost a dead silence which to those knowing what this track meant to Kentucky can be called a silent tribute to the men whose work and industry turned these fertile Blue Grass acres into a monument to the thoroughbred racehorse." 23 The first race ever held at Keeneland, "The Top Flight," was a six-furlong allowance affair for two-year-old fillies. John Hay Whitney won the race with Royal Raiment in a time of one minute, twelve and one-fifth seconds. Kentucky's Lieutenant Governor at the time, Keen Johnson, presented Whitney with the first trophy ever given to the winner of a race at Keeneland. Six more races were on the card for Keeneland's inaugural meeting. Editors of The Thoroughbred Record concluded that Keeneland's first day of races "can mean but one thing, executive ability of the highest order on the part of those in charge." 24 The horsemen of Kentucky had realized their vision of a model racing venue and they must have felt magnificent.

The inaugural fall meeting at Keeneland closed on Saturday October 24, 1936. At the track that day were nine thousand horse enthusiasts and, as was the desire of 
Keeneland's founders, the patrons came to admire the horses as much as they did to bet on them. "That the interest was in the horses rather than 'the tote' the well-worn path to the paddock clearly showed" was how the editors of The Thoroughbred Record described the crowd's interest on the final day of Keeneland's initial racing meet. 25 On December 31,1936, Keeneland's financial operators published the financial statement for the track's opening year of racing. The statement showed a net loss of three dollars and forty-seven cents.

Six months later in April 1937, Keeneland held its first spring meet that marked the first springtime racing in Lexington since the Kentucky Association track closed four years earlier. The meet started on April 17 and continued through April 29. Keeneland's operators scheduled four stakes races, the Phoenix Handicap, the Ben Ali Handicap, the Lafayette Stakes, and the famed Blue Grass Stakes, for the spring meet. In John D Murphree's 1937 article, "Activities go on Apace at Keeneland," he opined "it is really difficult to invoke enough patience to await the spring opening of Keeneland. Visitors to the beautiful course find themselves yearning for a sight of horses ...." 26 The previously held fall meet was merely a prelude to the excitement the spring 1937 meet produced. Coupled with the second fall meeting in October 1938, the Keeneland Association showed an operating profit of almost $\$ 45,000$ from its first full year of operation. After the Association's treasurer deducted taxes, insurance, interest, and fixed expense costs of just over $\$ 24,000$, they reported a balance of nearly $\$ 21,000$. As promised by the horsemen, and guaranteed in the articles of incorporation, the Association allocated every penny of the profit for stock retirement and property improvements at Keeneland. Association president Hal Price Headley stated in a 
February 1938 interview, "Keeneland is no longer a dream, but a reality, and that with your continued support its success is assured." 27

Keeneland's formation started as a dream born from the horsemen of Lexington's desire to return racing to their city. The depression of the 1930 's, a family farm on the outskirts of town, and the desire of the Keeneland Association members intertwined to bring to Lexington the most unique racing and horse facility in the United States. The final product was more advanced and unique than they imagined. What Keeneland became over the decades was true to the desire of the original members of the Keeneland Association. The Association's directors have watched the horseracing industry grow to greater heights over the past seven decades. While Keeneland has shared in that growth, it remains a quiet, yet powerful venture on the outskirts of Lexington. The final chapter canvasses the phenomenal survival of Keeneland as a small, cosmopolitan track amid the growing horse tracks and horse industry that surround it. 


\section{CHAPTER THREE THE PHENOMENAL SURVIVAL OF KEENELAND}

Keeneland's economic survival as a small, cosmopolitan track amid the large corporate ventures of the twenty-first century horseracing industry forms an astonishing story. Multi-million dollar physical expansions and alternative gambling kickbacks prevail at such popular tracks as Churchill Downs, Aqueduct, and Louisiana Downs. But the Keeneland Association has remained faithful to its founder's mission of operating a thoroughbred horse facility solely for the betterment of the horse industry and the horsemen of Kentucky's Bluegrass region. Association members dealt with world wars and economic depressions in the past and currently face fierce competition for gambling dollars from the influx of riverboat casinos. In addition, in 2001 Keeneland confronted not only a mysterious equine disease that resulted in the loss of thousands of Kentuckybred yearlings but also competition from the trendy modernization of tracks throughout the United States. But Keeneland has survived as a center for thoroughbred racing and sales unlike any venue in the United States. This chapter examines Keeneland's evolution into a horseman's utopia with the highest race purses in the country, enormously popular horse sales, an unrivaled research library, and the commitment of the Keeneland Association to sustain the original purpose of "the most regal track in the United States." 1 The major thesis of this material will be that Keeneland has survived as an small, cosmopolitan track by turning their profits into higher purses and planning 
internal improvements based on the tradition of Keeneland, rather than the fashionable modern expansions and high administrative salaries of other United States racetracks.

Sport and horseracing historians have published little or no scholarship on Keeneland's economic survival. Canvassing three major university libraries, two historical associations, rare book collections, and Keeneland's own repository for the fabric of this chapter revealed little, if any, material. The sports and racing historical literature barely mentioned the most economically and lucrative aspect of Keeneland, its famous yearling sales. The economic survival of Keeneland is another unique aspect to the entire Keeneland story, equal to its founding by horsemen of central Kentucky. That the Keeneland Association survived into the twenty-first century as a non-dividendpaying corporation reflects positively on the entire horse community of Lexington and central Kentucky. These horse enthusiasts helped keep the mission and goals of Keeneland's founders by contributing the finest horses for races, sales, and shows. That no scholarship was published on the enormous financial numbers for Keeneland's purses, sales, and charitable contributions suggests both the need for such a history and the tightness of the fraternity that exists among horse enthusiasts. Even more puzzling was the neglect of scholarship on Keeneland's importance to the livelihood of the nearly 500 horse farms that surround it. 2 Periodicals such as The Blood Horse, $\underline{\text { Horse and }}$ Horseman, and The Thoroughbred Record proved invaluable in bringing to light the staggering financial numbers of Keeneland's operations.

The Keeneland Association remains true to the 1935 prospectus written by its original members. By funneling profits into the daily racing purses, the Association does not worry about survival or raising its director's compensation, because they receive 
none. Having a racing facility conducive for the horsemen and horse enthusiast of central Kentucky has been prevalent at Keeneland throughout its history. Starting with its first meet in 1936 and continuing throughout the remaining decades of the twentieth-century, every economic measure for a successful racetrack steadily increased at Keeneland. Through the 1940s and 1950s, racing days, attendance, and mutuel handle increased slowly but steadily. The administration at Keeneland was viable and steady. In 1940, members of the Keeneland Association elected Louis Lee Haggin as president of the Keeneland racecourse. Haggin served in this capacity until 1956 (he was elected president of the Association in 1956 and served in that role until 1970). Haggin and the Association's first president, Hal Price Headley, provided their guidance and leadership for Keeneland that lasted through the 1950s. In 1943, the Keeneland Association entered the yearling horse sales that became one of Keeneland's signature events. In 1953, Keeneland's first physical expansion enlarged the grandstand that included a dining facility. By the end of the 1950 s, the Association constructed a five-furlong training track on the grounds and oversaw a $\$ 150,000$ overhaul of the main track. In its first twenty-five years of operation, Keeneland's administrators proved themselves to be successful stewards of the founders' mission.

The next thirty years of operations at Keeneland proved to be an enormously prosperous period. Through the growing popularity of the yearling sales, higher attendance, upgraded races, and increasing purses, Keeneland became one of the most exalted racing and horse facilities in the United States. Since 1960, Keeneland's attendance has increased nearly every year, its mutuel handle tripled by 1990, and its purses and graded stakes races steadily increased. By 1990, the Keeneland Association 
witnessed hundreds of millions of dollars pass through the sales pavilion, ticket windows, and purse distributions. By that time, the racing industry had changed dramatically. For example, states introduced off-track wagering at racetracks around the country and the breeding of horses became multi-million dollar operations. The Keeneland Association was aware of, and embraced, the changing nature of the industry. But they did not change Keeneland's mission to provide a facility for "sportsmanship, rather than commercialism ... a show window, as it were, for this section's great thoroughbred horse industry." 3

By the end of the twentieth century, the leaders of Keeneland kept the mission of its founders alive while remaining competitive in the industry. At the close of the decade, competition for the gambling dollar was a concern across the industry because of an aging fan base and the many alternative gambling ventures such as online wagering and the rise of legalized riverboat gambling. Among the numerous examples are Saratoga Springs in New York and Tampa Bay Downs in Florida. Directors at Saratoga Springs installed video lottery terminals in 2003 and operators at Tampa Bay Downs opened a card room that included fourteen tables for poker games. In addition, in the first years of the twenty-first century, track managers cut purses throughout tracks around the United States. For example, in January 2004, track administrators at Santa Anita Park in Los Angeles, California slashed purses by $6.5 \%$ and cut their graded stakes program by $\$ 450,000$. Yet Keeneland's unique status insulated the institution from these concerns and patrons continue to attend the untraditional and quirky racetrack. Annual attendance at Keeneland has grown steadily over the previous five years from just over 391,000 in 1998 to nearly 445,000 in 2003 . The on-track handle has been over $\$ 40,000,000$ for each 
year of the twenty-first century and over $\$ 37,000,000$ for the past five years. With the various off-track totals figured in for the same period, the total handle has never been below $\$ 185,000,000$. In 2003 , the total handle figure was just over $\$ 253,000,000$. Considering the competition from the new alternative gambling ventures and the enormously larger tracks found elsewhere throughout the country, Keeneland's financial numbers are grand indeed. 4

On January 3, 2004, Tom LaMarra published an article in The Blood Horse magazine entitled "Decision 2004?" in which he noted that "Kentucky is in a state of status quo ... purses are stagnant, and on-track betting, with the exception of Keeneland, continues to decline. " 5 Examination of Keeneland's purse figures reveals further evidence that Keeneland is a distinguishably unique racetrack. The highest average purses in the United States are at Keeneland. While the industry's average purses among all racetracks have declined in the most recent years of the twenty-first century, Keeneland's have remained steady. In 2003, Keeneland's races had a daily median purse of $\$ 50,000$, the highest of any track in the United States. By comparison, the median purse for the same year at Belmont Park in New York State was $\$ 44,000$. Purses at Hollywood Park in California averaged $\$ 37,000$, and Churchill Downs in Louisville, Kentucky averaged just $\$ 35,720$. In addition, Keeneland's daily average purse for the same year was ranked second of all tracks in the United States, down just 0.6 percent from its number one ranking of 2002. In 2003, Keeneland's daily purses averaged slightly under $\$ 605,000$ and over $\$ 608,000$ in 2002 . By comparison, Belmont Park's 2003 figure was $\$ 556,960$ and Churchill Down's was $\$ 433,462$. Even more peculiar than the purse figures was the number of racing dates the directors of Keeneland hold each 
year. The Association scheduled only thirty-two dates in 2003 and has scheduled only twenty-nine to thirty-five racing days since 1966 . In 2003 by comparison, race managers at Belmont scheduled ninety-three days, Hollywood Park hosted ninety-five meets, and Churchill Downs' managers scheduled seventy-nine. It is an exceptional story in modern horseracing that Keeneland is open one-third of the days that many of the industry's tracks operate, in a facility that seats merely 7000 people and charges three dollars general admission (which just started in 2003), and yet still thrives as the showcase for thoroughbred horses in the United States. 6 Further, Keeneland's purses have not been supplemented by any outside gambling alternatives such as slot machines or casino kickbacks, as many of the tracks are beginning to do around the United States. The original mission of the founding members is intact at modern-day Keeneland. The philosophy of the Keeneland Association founders and of its first president Hal Price Headley to construct a model racing plant, "where those who love horses can come ... and thrill to the sport of the Bluegrass. We are not running a race plant to hear the click of the mutuel machines," remains the same mission for the Keeneland Association in the twenty-first century. 7

Despite the limited racing days, Keeneland's racing managers hold numerous graded stakes races (the highest paying races in the industry) every year, including six Grade I events (the highest quality races in the industry). 8 The original members of the Association organized many now-famous stakes races for Keeneland's first two meetings in 1936 and 1937. The directors organized the Grade I Ashland Stakes for Keeneland's first fall meet in October 1936. Organizers named the race after the estate and breeding farm in Lexington of politician and statesman Henry Clay. The race is for three-year-old 
fillies and a $\$ 500,000$ purse. The Grade I Blue Grass Stakes is a $\$ 750,000$ race organized by the Association for Keeneland's first spring meet in April 1937. The race was first run at the old Kentucky Association track in 1911 and was named by its patrons after the region of central Kentucky known for the best thoroughbreds in the United States. From its genesis at the old Association track, the Blue Grass Stakes has served as one of the most important prep races for the Grade I Kentucky Derby held traditionally on the first Saturday in May in Louisville. Another graded stakes race at Keeneland is the Ben Ali Stakes, a Grade III race with a purse of $\$ 150,000$. Managers of the Kentucky Association track first organized this race in 1917. The race is named after the famous central Kentucky horse breeder and financier James Ben Ali Haggin. In 1937, the Keeneland Association rejuvenated the race at Keeneland's first spring meeting. The Grade III, $\$ 100,000$ Lafayette Stakes is run at Keeneland every spring as well. Named by its founders after the Lafayette Hotel (no longer in existence) in downtown Lexington, the Keeneland Association started this race for three-year-olds at the first spring meet. Finally, the Association hosts the Grade III Phoenix Breeders' Cup, originally named and held in 1831 by the Kentucky Association's operators. This race is known today by its affiliation with the Breeders' Cup Association. Over its history, the directors of the Kentucky Association and Keeneland renamed the race seven times. It is currently named for the old Phoenix Hotel in downtown Lexington. The Phoenix Breeders' Cup, with a purse of $\$ 250,000$, is the oldest stakes race in the United States. The Keeneland Association first held this race at the Keeneland course during their initial spring meet. These five graded stakes races constitute some of the oldest stake races in the United States as well as the initial stake races held at Keeneland. As of 2003, the total purse 
money for these five races totaled $\$ 1,750,000$. In all, the Keeneland Association holds nearly forty stakes races for its meets in the months of April and October. That figures to more than one stakes race a day at Keeneland, a low figure that is unheard of in modern racing.

The largest economic endeavor for the Keeneland Association is the Keeneland yearling sales. These sales have been the top yearling sales in the United States for decades and have become the top sales throughout the world. Horsemen from such places as the Middle East, Asia, and Europe come to Lexington every year to participate in the sales. Started by Keeneland's management under a tent in the paddock area in 1938, the yearling sales have evolved into a financially astounding event. Over the years, directors of the sales have expanded the operation to include breeding stock and horses of all ages. These sales are equally successful as the yearling sales and they heighten the enthusiasm for the event.

The original prospectus for Keeneland in 1935 included provisions that Keeneland serve as a facility for "other horse sports" and "horse activities ... in keeping with the cherished reputation of the Blue Grass Region as a great pleasure horse producing country." 9 The most recognized of these "activities" are the Keeneland horse sales. On April 25, 1938, directors of the Association organized the first horse sales at Keeneland in the open paddock area. The auctioneer took bids on thirty-one various thoroughbreds totaling $\$ 24,885$, an average of $\$ 802.74$. The highest price paid by a bidder that April day was $\$ 3500$ for a mare named Marmitina. While the small, initial thoroughbred sale started a new tradition at Keeneland, it was in the sale of yearlings that the Keeneland Association made its mark in the industry. Throughout the twentieth and 
into the twenty-first centuries, no other yearling sales in the United States have been as prestigious and profitable.

The Association held its inaugural yearling sale in 1943. Before the Keeneland sales, Kentucky horse breeders and owners regularly sent their yearlings around the country to sell. The most noted sale at the time was conducted by the Fasig-Tipton horse operation at Saratoga Racetrack in New York State. By 1943, with the United States entered into World War II, the federal government restricted railway transportation, the major form of transportation for horses. These restrictions forced Kentucky horsemen to keep their yearlings in the state. World War II was the only time in Keeneland's history that racing dates were canceled. Directors of Keeneland moved their spring racing meets to Churchill Downs for the 1943-1945 meetings. But the Association members formulated an idea to hold the sales despite the loss of scheduled racing. The Association members offered the opportunity for the directors of the Fasig-Tipton sales to come to Lexington from August 9-11, 1943, and conduct their sales at Keeneland. Directors of Fasig-Tipton agreed to the arrangement and Keeneland's operators had a tent constructed outside the grandstand and paddock areas adjacent to the horse sheds. On August 9, 1943, the Association organized its first ever-yearling sales at Keeneland. Horse owner Fred W. Hooper bought the 1945 Kentucky Derby winner, Hoop, Jr., at the sale.

Keeneland's entrance into the sales aspect of the thoroughbred industry marked the beginning of the most prestigious and well-known horse sales in the United States. No other horse sales in the country brought the prices for horses like the sales at Keeneland. These sales, and the prices paid for the thoroughbreds, solidified central Kentucky and Lexington as the premier thoroughbred center in the United States. In 
1944 , following the initial yearling sales on the grounds at Keeneland, the members of Fasig-Tipton opted not to participate at any level with the sales in Lexington. Hal Price Headley and A.B. Hancock, Sr. formulated a cooperative plan for the sales that would not interfere with the racing operations at Keeneland. Their idea was to hold the sales at different intervals throughout the year at times that would not interfere with Keeneland's racing dates. Headley and Hancock named the cooperative sales organization the Breeders' Sales Company.

Keeneland's yearling sales attracted buyers from all over the world and these sales are the most anticipated yearling sales in the industry. After Keeneland's own first yearling sale in 1944 when breeders sold 137 yearlings, operators of the Breeders' Company arranged for three sessions each year in July, September, and November. The November sales focused on breeding stock. In 1956, the Association members expanded the sales to include a horses-of-all-ages sale in January of each year. In 1993, the Association added a two-year-old in training sale to be held by the organization each year in April. Finally, the members added another yearling sale in 2001 that was to be held each October. The sales have turned into multi-million dollar auctions participated in by well-known horsemen around the world. Sports writer Billy Reed published an article in 1986 entitled "Keeneland: A Half Century of Racing," that declared Keeneland's horse sales, particularly the July sales, have "long been the world's most prestigious horse auction ... you can almost hear the doors of bank vaults swinging open in New York, London, Saudi Arabia, Tokyo, and everywhere else that high quality horseflesh is coveted." 10 
The prices commanded at the Keeneland sales have been enormous. In 1976, a group of Canadian horsemen bought from the sales the first yearling in history to ever sell for a million dollars. The owners sold the horse, Canadian Bound, a son of Triple Crown winner Secretariat, for $\$ 1,500,000$. In 1981 , the Aston Upthorpe group, on behalf of Middle East horsemen and oil businessman Sheikh Mohammed bin Rashid al Maktoum, bought Shareef Dancer for $\$ 3,300,000$. Its owners sold that same year, Ballydoyle, a son of Northern Dancer, to a group from Ireland, BBA Ireland, for $\$ 3,500,000$. By the mid-1980s, bidders bought horses at Keeneland in excess of $\$ 10,000,000$. While prices dipped in the late eighties and throughout the nineties, hundreds of millions of dollars were paid by bidders each year up through the beginning of the twenty-first century. In 2000 , horses sold for a combined gross of nearly $\$ 755,000,000$, the highest gross ever at Keeneland. Bidders paid nearly $\$ 689,000,000$ in 1999 and almost $\$ 557,000,000$ in 2001 , the second and third highest totals, respectively. As of 2004, breeders have sold sixteen Kentucky Derby winners, fifteen Preakness Stake champions, and twelve Belmont Stake winners at the Keeneland sales. In addition, as of 2004, Keeneland sales horses have won forty-three Breeders' Cup races. 11

The Keeneland Association sales have withstood tragedy as well. On September 11, 2001, Keeneland's management canceled the day's session after the terrorist attacks in New York and Washington. The cancellation marked the first time in its history that the Association called off a single-day session of the sales. In addition, the popularity and quality of the sales have survived one of the most disastrous diseases in the history of the thoroughbred industry. In 2001, the mare reproductive loss syndrome (MRLS) was a "baffling plague" that "left the state's [Kentucky] famed pastures empty some 3000 foals 
..." 12 The University of Kentucky released a study in 2002 that concluded the eastern tent caterpillars caused the outbreak of MRLS. The disease was responsible for a thirtypercent drop in foals for Kentucky thoroughbred breeders in 2001. In 2002, MLRS returned to the horse farms, although not to the devastating level of the previous year. Because of the plague, the Keeneland yearling sales operation was in danger of losing its product. In 2003, for the first time in its history, Keeneland directors canceled the entire July sales, "where fortunes ebb and flow as buyers gamble their dollars, pounds, francs, marks, yen and lira - - - not to mention their hopes and dreams - - - on the procession of sleek, nervous, blueblood yearlings led through the rings. "13 But in a testament to the importance of Keeneland and its thoroughbred horse traditions, the sales have survived and continue in spite of the devastating plague. Keeneland's sales administration decided to incorporate the lost July sales into the first two days of the September sale. The September 2003 yearling auction generated an average price of $\$ 92,293$, with a median price of $\$ 34,000$, both of which were September sales records. The sales increased almost thirty percent from the previous year and generated nearly $\$ 274,000,000$, the second-highest total ever for a Keeneland September sale. In January 2004, the operators canceled the July 2004 sales because of the leftover effects of MRLS and, in large part to "the overwhelming success of this year's Keeneland September yearling sales." 14 In addition, Keeneland's November 2003 breeding stock sale was the fourth highest grossing auction in its sixty-year history. Bidders at the November sales set records for the highest price ever paid for a broodmare, as well as the North American sales record for a weanling colt. The broodmare, Cash Run, auctioned for $\$ 7,100,000$ and the weanling, an unnamed son of Storm Cat and Spain, sold for $\$ 2,400,000$. For 2003 , the 
combined yearly sales at Keeneland rose by over fourteen percent. The sales grossed $\$ 562,822,200$ despite the loss of thousands of yearlings in the previous two years. For the April 2004 two-year-olds in training sale, the Association cataloged 256 horses, the highest number ever for the April sales and three more than the previous mark set in 2003. 15 These figures reaffirmed the strength of the sales as well as their unique and considerable status in the horse industry despite the effects of "an unprecedented blow [MRLS] . . that will hurt nearly every section of central Kentucky's economy." 16 The fall sales set new records that eased the fears of Keeneland and the entire central Kentucky thoroughbred industry's workforce.

True to their original purpose, the Association has continued the internal improvements to Keeneland into the twenty-first century. The operators have been aware that Keeneland holds the distinction as the most unique and regal racetrack in the United States, and they strive to keep that tradition. As the original prospectus provided, the Association funnels portions of profits into capital improvements on the grounds and physical buildings. But Keeneland's directors have been slow and careful to change since opening the facility in 1936. Ten years passed before the operators installed a photo-finish camera. The Association did not replace the wooden railing and seats in the boxes with aluminum and steel until 1950. They did not add a new sales pavilion until 1969. New barns were not added until 1973 and the grandstand was not updated to concrete and steel until 1976. A second entrance into the grounds was not opened until 1983. While Keeneland has received revenue from simulcast wagering, it did not do so until 1988, long after states like New York started participation in the early 1970s. And Keeneland did not use a public address system for races until 1997 when the Association 
hired announcer Kurt Becker to announce the spring meet. 17 Although Keeneland's management keeps the facility current within the industry in such areas as the effect of alternative gaming on horseracing, new products for racing surfaces, and updated railings for gates and tracks, they are cautious about past tradition when it comes to physical change. In 2003 Lexington writer Amber Scott published an interview in $\underline{\text { Southsider }}$ Magazine with the Keeneland Association's current president Nick Nicholson that reflected his understanding of Keeneland's traditions. Scott quoted Nicholson regarding change at Keeneland: "If you make a change in one area, it impacts four or five areas. You have to be careful about what you do ... there is something special about this place." 18

Another avenue that aids in keeping Keeneland's original commitment is the member's pledge of financial giving. No racing venue in the United States matches the Keeneland Association's financial contributions to its community. The Association members have highlighted the non-profit status of Keeneland by donating major contributions to charitable, research, and educational foundations. In 2003 for example, the Keeneland Association gave the Kentucky Historical Society $\$ 50,000$, the YMCA of Central Kentucky $\$ 50,000$, and the United Way of the Bluegrass $\$ 30,000$. These funds were merely three of sixty-nine organizations that received contributions from the Keeneland Association in 2003. The Associations total charitable contributions for 2003 amounted to over $\$ 600,000$. Since its founding in 1935 , the Association has contributed over $\$ 5,000,000$ to various organizations in Fayette County alone. In the same period, groups in other central Kentucky counties, such as Bourbon, Woodford, Scott, and Jessamine, have received nearly $\$ 3,000,000$ in aid from the Association. In addition, the 
Association has donated nearly $\$ 4,000,000$ to education and research-based universities and colleges. The nearby institutions, such as the University of Kentucky, Transylvania University, Midway College, and Kentucky State University, are among the nineteen colleges and universities that have received aid from the Association. Keeneland's trustees have given over $\$ 3,000,000$ to these institutions. These educational institutions have used these monies for various expenditures such as new library additions, salary supplements, science laboratory equipment, and agricultural experimentation. The research-based organizations receiving money from Keeneland have included, among others, the Grayson-Jockey Club Research Foundation and the Kentucky State Police Laboratory. Interestingly, Keeneland's bylaws state that if the Keeneland Association is dissolved, all net proceeds from the sale of assets must be donated to tax-exempt organizations. Since its founding by the horsemen of Lexington, the Keeneland Association has given away nearly $\$ 12,000,000.19$

Another aspect to the unique nature of Keeneland is its research and reference facility. The original members of the Association's desire for the formation and construction of a library was realized with the opening of the Keeneland Library in 1939. Keeneland's administration relocated the library to a new building in July 2002 and it is the most exclusive research and reference library for horses and horseracing in the United States. The library's setting, collections, and purpose are unique and have no comparison at any track in the United States. In 1939, horse enthusiast and Keeneland director William Arnold Hanger donated a collection of horse related material to the Keeneland Association. His collection came from the volumes of material he purchased from New York lawyer and horse enthusiast James Turnbull. Turnbull built a collection of 
scholarship on the origins of the thoroughbred horse. Hanger purchased over 2000 volumes of Turnbull's material and donated every piece to Keeneland. In addition, horseracing photographer Charles Cook sold his collection of racing and racetrack photos to the Association in 1959 , and in 2000 , the Daily Racing Form donated its entire archives for inclusion in the library. In 2002, the Keeneland Association organized construction of and relocation to a new limestone building for the library adjacent to the Keene Barn and Entertainment Center, near the Man O' War Boulevard entrance. The new building opened in July 2002. The library contains a rare book room, computer stations, and rare photograph room. The 3200 square foot building is temperature and humidity controlled, with over 10,000 accessible volumes of general racing and horse material. The inclusion by the Keeneland Association of a library with "the most complete collection of turf literature to be found in the world" located on the grounds at Keeneland fits with the ${ }^{\cdots}$ ') ose of Keeneland's founders. 20

Keeneland's pas: 4 current administrations have remained true to its original founders. They have not forgotten the desired purpose for Keeneland by such Kentucky horsemen as Major Louie Beard, Hal Price Headley, and A.B. Hancock. In a 1997 article entitled, "New Traditions for Keeneland," sport columnist Mike Bass observed that "Keeneland is not simply a backdrop for racing, it is much of the attraction, a museum unsullied by time and technology." 21 Keeneland's popularity among the horse enthusiasts of Kentucky - - - and the world - - - continues into the twenty-first century. Keeneland's patrons have set record figures for single-day and daily average attendance within the past ten years. While attendance at numerous racetracks around the United States has steadily declined, Keeneland's figures reflect steady growth and commitment 
to its mission. Association president Nick Nicholson echoed this mission by stating that "Keeneland plays an important part in a lot of different lives - - - from charity work, to community work, to horse work, to our employees, to farm owners, to the people who work on those farms. We have a lot of responsibility to those constituents. The conclusion is that there is something special about this place, and the place deserves it. She deserves all the good feelings that people have about her, and it's our responsibility to nurture that to pass it on hopefully better than we found it." 22 With these sentiments, Nicholson echoed the past and helped ensure that the original purpose for Keeneland continues into the future. 


\section{CONCLUSION}

The horses stretched out over the track. Their strides, each twenty-one feet in length, fell in perfect synch. They rubbed shoulders and hips, heads snapping up and reaching out together, legs gathering up and unfolding in unison. The poles clipped by, blurring in the rider's peripheral vision. The speed was impossible; at the mile track, a fifteen-year-old speed record fell under them, broken by nearly a full second. The track rail hummed up under them and unwound behind .... Clem McCarthy's voice was breaking into his microphone. "Seabiscuit by three! Seabiscuit by three! He had never heard such cheering. Arms waved and mouths gaped open in incredulity as Seabiscuit came on ... The Iceman straightened out and rode for the wire, his face down. Seabiscuit sailed into history four lengths in front, running easy. 1

Horseracing author Laura Hillenbrand's description of the drive down the backstretch in the 1938 match race between Seabiscuit and Triple Crown winner War Admiral, "still widely regarded as the greatest horse race in history," was a microcosm of horseracing's enormous popularity throughout the history of the United States. 2 Sports enthusiasts identify thoroughbred horses such as Seabiscuit, Man $O^{\prime}$ War, and Secretariat as some of the most recognizable names in the history of popular sports culture. As horseracing's popularity grew through each passing decade of United States history, thoroughbred racing's signature affairs, the Triple Crown and Breeders' Cup Championships, evolved into two of the most highly attended and visible sporting events in the first decade of the twenty-first century.

Sport and recreational activities had an extensive history of their own within United States history. The growth of sport and leisure activity in the United States has 
evolved from traditional rural games to sophisticated sports teams (and betting) and the scale and scope of sports and recreation have reached an astonishing level. Sports as an enterprise have grown from their beginnings in colonial America to the multi-billion dollar industry of the twenty-first century. In modern times in the United States and around the world, millions of spectators applaud the successful athlete and athletic teams above the most famous political, religious, and education leaders of the day.

The historiography of the United States sport and recreational history is vast. This scholarship expanded in the 1980s as sport and leisure historians sought to explain their enormous growth in popular society. During the eighties, the sporting fraternity witnessed the birth of the multi-million dollar athlete and clubs as salaries, attendance, and participation in sporting events soared. Serious sport and recreation literature grew with sport's popularity. Sports writers and historians have crafted a variety of interpretations in explaining how sport and recreation formed one of the nation's most vibrant and continuing cultural institutions.

No recreational activity in United States history extended to the reaches of all classes or generated the excitement for sport earlier than horseracing. In the United States, horseracing is no longer "the sport of kings" participated in only by society's elite. Horseracing constitutes the oldest and most celebrated sport and recreational activity in the history of the United States. As historian John Rickards Betts succinctly observed, "the roots of our sporting heritage lie in the horse racing ... of the colonial era." 3 From the settlement at Jamestown in the first decade of the seventeenth century through the present day, Americans have raced horses. Horse enthusiasts organized races in the United States from the makeshift dirt paths in colonial America to any of the numerous 
racecourses found in the United States in the twenty-first century. Colonists developed and expanded horseracing's popularity in such tidewater colonies as Maryland, Virginia, and in the ex-Dutch colony of New York. Yet nowhere did the horse and horse industry flourish and compose a unique and vital role in a state's social history and economy than in the western counties of Virginia, in Kentucky. The horse industry is Kentucky's most popular industry, above the state's profitable enterprises of tobacco, whiskey, bourbon and the illegal crop of marijuana. Central Kentucky, with Lexington at its core, is the foremost region in the United States for breeding and rearing of thoroughbred horses. It is in this Bluegrass region of central Kentucky that horseracing's long and developing story lies. One of the exceptional stories in the vast opus of United States sport and recreational history is the founding and economic history of Keeneland racecourse.

The formation and founding of Keeneland racecourse by a group of central Kentucky horsemen in the late 1930s is one of the most unique events in United States horseracing history. But the history of Keeneland, "America's model race track" is largely an untold story. 4 Historical research and scholarship on "the most regal track in the United States" is minimal and reconciling this lack of research on this important cultural institution is difficult, given the large amount of publication produced by historians in the field of horse and racing history. 5 Keeneland's unique story is one worth telling. It is a story of vision and perseverance that personifies the Commonwealth of Kentucky's ties to the horse and the industry of horse racing.

The two entrances to Keeneland contain the gateposts from the old Kentucky Association track. The green colored posts with an interlocking "KA" in the middle are reminders to the thousands of Keeneland patrons of horseracing's extensive and 
unequaled history in central Kentucky. In 1938, Kentucky author Elizabeth M. Simpson stated in, The Enchanted Bluegrass, that "Keeneland is so much a part of all that is dear in Kentucky ... so definitely a symbol of the finest, the proudest, the most colorful in this Enchanted Bluegrass - - - it isn't possible to be impersonal about it." 6 The citizens of central Kentucky are connected to Keeneland in ways that are not matched by any racing facility anywhere in the United States. The livelihood of numerous central Kentucky thoroughbred enthusiasts, breeders, owners, farm operators, and trainers are attached to Keeneland through various aspects of the horseracing industry. No other racing facility in the country provides a showcase for the thoroughbred horse or the sport of horseracing that Keeneland does. In addition, its location on the Keene family farmland, its stunning architecture, the scale of its operations, its grand horse and yearling sales, and recently its exceptional library, makes Keeneland unequaled by any racetrack in the United States.

In 1933, the administration of the Kentucky Association racecourse in Lexington closed the track, at the time the oldest operating racing venue in the United States. Two years later, a group of forward-thinking Lexington horsemen organized plans for "a model racing plant" in Lexington. 7 The founding members of the Keeneland Association established Keeneland "to make for Blue Grass Kentucky a show window, as it were, for this section's great Thoroughbred horse industry." 8 The members insisted that Keeneland be operated on a non-profit basis. Horsemen such as Hal Price Headley and A.B. Hancock formulated this non-profit idea in the concluding years of the greatest economic depression in United States history, adding an even more unexpected aspect to Keeneland's history. Their goal of opening "a racing ground and horse activities center 
at Lexington, Kentucky in keeping with the cherished reputation of the Blue Grass Region" on a non-profit basis proved to be an extraordinary event. 9 The horsemen's objective was to open a facility operated by central Kentucky's horse enthusiasts for the betterment of the industry in Kentucky and to showcase their state's most distinguished product. Throughout the history of Keeneland, its operators have funneled profits into purses that make Keeneland's the highest in racing and for upkeep and improvements to its facilities, racecourses, and grounds.

Keeneland's economic survival as a small, cosmopolitan track amid the larger venues of the twenty-first century adds to its distinction. The Keeneland Association has remained faithful to their founder's mission and expanded Keeneland's influence throughout the industry. By the beginning of the twenty-first century, horse enthusiasts from around the world descend on Lexington and spend nearly $\$ 1,000,000,000$ at Keeneland's sales and betting windows every year. Keeneland and the Keeneland Association thrives despite scheduling the fewest racing dates of all thoroughbred tracks in the United States, not selling shares of stock on the stock exchange, or receiving any monetary kickbacks from the popular alternative gambling ventures of the twenty-first century. Keeneland has survived by the Association member's commitment to its original mission of operating a facility that showcases Kentucky's premiere thoroughbreds. In her 1986 article entitled, "A Dream Fulfilled," horseracing journalist Deidre B. Biles argued, "Keeneland, in its $50^{\text {th }}$ year, is not unlike a mature lady. She does not oppose progress, yet in her respect for tradition, makes no changes in herself without long thought as to their consequences." 10 The Association remains true to its 1935 prospectus envisioned and started by the horsemen of central Kentucky. 
Researching and studying the history of United States sports and recreational history demonstrates that popular sporting culture adapts and changes to the societal contexts that surround it. Throughout the sporting history of the United States, participation at every level of sport and recreation has withstood obstacles such as religious suspicions, hostile popular majorities in legislatures, world wars, and economic catastrophes. Sport and leisure activities have evolved through the emergence of distinct American social contexts and economic developments. American sports have reflected society's values throughout United States history. Historian John F. Rooney argued in, $\underline{A}$ Geography of American Sport: From Cabin Creek to Anaheim, that "the popularity of a certain sport or sports in any region is a result of the combination of historical, social, economic, demographic, and environmental conditions." 11 Sports commentator S.W. Pope claimed in, The New American Sport History: Recent Approaches and Perspectives, that sports "provide a dynamic, accessible window into politics, economics, gender, race, class formation, ideology, religion, and virtually every other topic." 12 No sport in the history of the United States reflected Rooney and Pope's statements like horseracing. No horseracing venue in the history of the United States has survived and thrived quite like the unique and remarkable Keeneland racecourse in Lexington, Kentucky. 


\section{Endnotes-Introduction and Chapter One}

1. The quote "sport of kings" was not attributed to any one author or book, but used as a commonly referred to synonym for horseracing. Horseracing is called the sport of kings mainly because of the fourteenth and fifteenth century English nobility's love of horseracing.

2. Richard Lipsky, How We Play the Game: Why Sports Dominate American Life (Boston, MA.: Beacon Press, 1981), 9.

3. The statement is a consensus to the works of Mrozek and Radar in the following three books: Donald Mrozek, Sport and American Mentality 1880-1910 (Knoxville, TN.: The University of Tennessee Press, 1983). Benjamin Radar, American Sports: From the Age of Folk Games to the Age of Spectators (Englewood Cliffs, N.J.: Prentice Hall, 1983). Benjamin Radar, American Sports: From the Age of Folk Games to the Age of Televised Sports (Englewood Cliffs, N.J.: Prentice Hall, 1990).

4. The statement came from surveying the field, of which Reiss' book was included. Steven A. Reiss, The American Sporting Experience: A Historical Anthology of Sport in American (Champaign, IL: Leisure Press, 1984).

5. Radar, American Sports, 21.

6. Peter Levine, American Sport: A Documentary History (Englewood Cliffs, N.J.: Prentice Hall, 1989), 2.

7. Ibid., 6 .

8. Radar, American Sports, 6.

9. Ibid., 6-7, 10.

10. Ibid., 11.

11. This material is a consensus of Radar's works in American Sports: From the Age of Folk Games to the Age of Spectators, and American Sports: From the Age of Folk Games to the Age of Televised Sports. 
12. Nancy Struna, "Puritans and Sports: The Irretrievable Tide of Change," 4 Journal of Sport History (Spring 1977): 2. This article was reprinted in Reiss' The American Sporting Experience, 16.

13. Ibid., 19.

14. Information on the Hanover County Fair came from Radar, American Sports, 15.

15. The quote appears in Ruth Painter's article "Tavern Amusements in Eighteenth Century America" in Leon Stein, ed., The Leisure Class in America (New York: Arno Press, 1975), 54.

16. "Gentlemanly" is the term used here as a consensus of research and scholarship on the different types of games participated in by the emerging classes of the eighteenth century. "Gentlemanly" is not a direct quote from any source.

17. Phillip Greven, The Protestant Temperament: Patterns of Child Rearing, Religious Experience, and the Self in Early America (New York: Knopf, 1977), 145.

18. Edwin A. Miles, "President Adams Billiard Table," 35 New England Quarterly (March 1972): 31.

19. Radar, American Sports, 25.

20. Douglas A. Noverr and Lawrence E. Ziewacz, The Games They Played: Sports in American History, 1865-1980 (Chicago, IL.: Nelson-Hall, 1983), 3.

21. The population figures are from the United States Census Bureau's web site. The link to the census figures is from the Unites States Government web site.

22. Noverr and Ziewacz, The Games They Played, 10.

23. John R. Gerdy, "Introduction" Sports: The All-American Addiction (Jackson, MS.: University Press of Mississippi, 2002), viii.

24. John Rickards Betts, American Sporting Heritage: 1850-1950 (Reading, MA.: Addison-Wesley Publishing Company, 1974), 27.

25. Ibid., 28.

26. Grob's quote was reprinted in Noverr and Ziewacz, The Games They Played, 12.

27. Ibid., 13. Noverr and Ziewacz reprinted Radar's article.

28. Mrozek, Preface to Sport and American Mentality: 1880-1910, xvi.

29. Ibid., xvi. 
30. Ibid., xvii.

31. The information on ticket prices was done through Major League Baseball's official web site. The average ticket price was my calculations based on ordering tickets to any major league baseball team's game. The tickets were available to the general public and were not special, boxed, or preferred seats.

32. Betts, American Sporting Heritage, 33.

33. Reiss, The American Sporting Experience, 41.

34. This material is contained in the brochure "An Introduction to the Thoroughbred Horse." This work is a special report prepared under the auspices of The Thoroughbred Owners and Breeders Association and was first published by the editors of The Blood Horse magazine in November 1942 in Lexington, Kentucky. The material here is contained on page 4 , but the editors have published multiple copies and condensed forms of the report. The report is included in the stacks at the University of Kentucky's William T. Young Library and at the Keeneland Library.

35. Francis Barnum Culver, The Blooded Horse of Colonial Days: Classic Horse Matches in America before the Revolution (Baltimore, MD.: Published by the author, 1922), 30.

36. Radar, American Sports, 21.

37. Alexander Mackay-Smith, The Colonial Quarter Horse Race (Richmond, VA.: Press of Whittet \& Shepperson, 1983), 7.

38. Riess, The American Sporting Experience, 42.

39. This material is contained in the brochure "An Introduction to the Thoroughbred Horse." This work is a special report prepared under the auspices of The Thoroughbred Owners and Breeders Association and was first published by the editors of The Blood Horse magazine in November 1942 in Lexington, Kentucky. The material here is contained on page 1, but the editors have published multiple copies and condensed forms of the report. The report is included in the stacks at the University of Kentucky's William T. Young Library and at the Keeneland Library.

40. Mackay-Smith, The Colonial Quarter Horse Race, 7.

41. Ibid.

42. The year 1679 was an estimate based upon the available scholarship on the Byerly Turk. The research was inconclusive on an exact year of birth. 
43. Ernest de la Grange, Horse Racing Through the Ages: Some Facts and Figures. (London: Studies Publications, 1932), 13.

44. This information comes from numerous sources. The history of the Goldolphin Arabian had to be pieced together from a variety of primary and secondary literature.

45. This material comes from piecing together numerous sources, much like the information on the Godolphin Arabian. The research was indefinite on the date of foaling, the Darley's move to Aleppo, and whether Thomas Darley sent the horse to his father or brother.

46. These thoroughbreds differed from the quarter horse in their speed and stamina. They could run further distances at faster speeds.

47. Culver, Blooded Horses of Colonial Days, 101.

48. Ibid.

49. Radar, American Sports, 20.

50. John H. Wallace, The Horse of America in His Derivation, History, and Development (New York: Published by the author, 1897), 91.

51. T. H. Breen, "Horses and Gentlemen: The Cultural Significance of Gambling Among the Gentry of Virginia," in Donald Spivey, ed., Sport in America: New Historical Perspectives (Westport, CN.: Greenwood Press, 1985), 4.

52. Levine, American Sport: A Documentary History, 9.

53. The Virginia newspaper mentioned here was the Virginia Gazette. The article appeared in Culver, Blooded Horse of Colonial Days, 111.

54. Ibid., 27.

55. Radar, American Sports, 15.

56. This material came from my consensus on the research about southern colonists and northern colonists starting their tradition of conflict. No historian stated this exact notion, but the statements here are my conclusions on a wide variety of research.

57. The Oaks race and the Darby race are not quotes from any particular source, but put in quotations to mark as proper names.

58. John Gilmer Speed, The Horse in America (New York: McClure, Phillips \& Company, 1905), 44. 
59. Ibid., 44-45.

60. Wallace, The Horse of America In His Derivation, History, and Development, 91.

61. Levine, American Sport, 19.

62. Ibid., 20-25.

63. Adleman's quote was reprinted in Donald Spivey, ed., Sport in America: New Historical Perspectives (Westport, CN.: Greenwood Press, 1985), 52.

64. Radar, American Sports, 84.

65. These numbers were my conclusion on the twenty-five racetracks open for operation in 1908.

66. Dean Alfange, The Horse Racing Industry (New York: Kensington Publishing Corporation, 1976), 13.

67. Ibid.

68. Hatton's term "Triple Crown" is not from any one research but put in quotations as a proper name.

69. "The most famous two minutes in sports" and "the dark and bloody grounds" are synonyms for the Kentucky Derby and the state of Kentucky, respectively, and are not quotes from any source.

70. Thomas D. Clark, A History of Kentucky (Ashland, KY.: The Jesse Stuart Foundation, 1992), 3.

71. Ibid., 11.

72. Ibid., 4 .

73. The West here refers to the West in the late eighteenth century with places such as present-day Kentucky, Indiana, Illinois, and Tennessee and not the modern day perception of the West.

74. Robert Peter, M.D. and William Henry Perrie, ed., History of Fayette County, Kentucky (Chicago, IL.: O.L. Baskin \& Company, 1882), 134.

75. Mary E. Wharton, ed., The Horse World of the Bluegrass (Lexington, KY.: John Bradford Press, 1980), 15. 
76. The information on the horse Diomed was a consensus of the information available on the horse. Specifically, that his useful day's were behind him.

77. Clark, A History of Kentucky, 73.

78. Lynn S. Renau, Racing Around Kentucky (Louisville, KY.: Published by the author, 1995), 33.

79. Charles R. Staples, Preface to The History of Pioneer Lexington: 1779-1806 (Lexington, KY.: University of Kentucky Press, 1996).

80. John D. Wright, Jr., Lexington: Heart of the Bluegrass (Lexington, KY.: Lexington-Fayette County Historic Commission, 1982), 1.

81. Staples, The History of Pioneer Lexington: 1779-1806, 96.

82. Ibid.

83. Ibid., 54.

84. Ibid., 102.

85. Ibid., 104

86. The copy of the Kentucky Jockey Club's resolutions was included in Marjorie Rieser's Master's Essay. Marjorie Rieser, "Horse Racing in Central Kentucky and Jefferson County (with special attention to Churchill Downs)" (Master's Thesis, University of Louisville, 1944), appendix.

87. Ibid.

88. Ibid.

89. The information on the Agricultural and Mechanical Society and the land came from Wright, Jr., Lexington, 41. 


\section{Endnotes-Chapter Two}

1. Thomas B. Cromwell, ed., "Status of Lexington Plans," The Blood Horse, 23 February 1935, 354.

2. The Keeneland Association, Inc., "Racing," in Keeneland Association, Inc. Thoroughbred Racing and Sales 2002 Media Guide (Lexington, KY.: The Keeneland Association, Inc., 2002), 4.

3. University of Louisville Local History Series, ed. Elva Ann Lyons, vol. 20, "Keeneland Race Track." (No publisher information given), 290.

4. "The Old Keene" is the term used as a reference by Lexingtonians to the Keene family farmland. "The Old Keene" phrase is not a direct quote from any one source.

5. Information here is a compilation of Ann Sims' material in University of Louisville Local History Series, ed. Elva Ann Lyons, vol. 20, "Keeneland Race Track." (No publisher information given), 290-306.

6. Ibid.

7. Ibid.

8. The statement here about the horsemen of Lexington was the opinion of the editors of The Blood Horse and The Thoroughbred Record throughout numerous articles. The information is not from one date or one article in either magazine, but a consensus on how the mood among the horsemen of Lexington was after the closing of the Kentucky Association track.

9. Thomas B. Cromwell, ed., "Kentucky Association," The Blood Horse, 12 January 1935,51 .

10. Ibid.

11. Thomas B. Cromwell, ed., "New Plans for Keeneland," The Blood Horse, 9 February 1935, 282.

12. Ibid. 
13. The statement here regarding the members of the informal association distributing the prospectus is a consensus of research from numerous articles.

14. Thomas B. Cromwell, ed., "Status of Lexington Plans," The Blood Horse, 23 February 1935, 354.

15. Ibid.

16. Ibid.

17. John E. Rubbathen, ed., "Price Headley Heads Organization to Finance New Track," The Thoroughbred Record, 23 March 1935, 198.

18. John E. Rubbathen, ed., "Price Headley Heads New Racing Organization," The Thoroughbred Record, 13 April 1935, 251.

19. Thomas B. Cromwell, ed., "Paragraphs," The Blood Horse, 22 June 1935, 744.

20. Ibid., 752.

21. John E. Rubbathen, ed., "Opening Day at Keeneland," The Thoroughbred Record, 17 October 1936, 230.

22. The Lexington Herald Co., ed., "Keeneland Course is Called Nation's Model Track: Bluegrass Welcomes Return of Thoroughbred Racing," The Lexington Leader, 15 October 1936, 1.

23. Raymond N. Gentry, "Here and There Among Horsemen," The Thoroughbred Record, 17 October 1936, 231.

24. John E. Rubbathen, ed., "Opening Day at Keeneland," The Thoroughbred Record, 17 October 1936, 230.

25. John E. Rubbathen, ed., "The Meeting at Keeneland," The Thoroughbred Record, 31 October 1936, 262.

26. John D. Murphree, "Activities go on Apace at Keeneland," The Thoroughbred Record, 3 April 1937, 305.

27. John E. Rubbathen, ed., "Keeneland Shows Profit," The Thoroughbred Record, 12 February $1938,140$. 


\section{Endnotes-Chapter Three}

1. Shane Dubow, "High Stakes in the Bluegrass," National Geographic, May 2003, 92.

2. The reference here to the 500 horse farms includes farms in the areas of Fayette, Bourbon, Jessamine, Woodford, Scott, Boyle, Franklin and Madison counties.

3. Thomas B. Cromwell, ed., "Editorial Notes: Background," The Blood Horse, 27 April 1935, 551.

4. The date and figures here came from numerous articles and was a consensus of all the compiled material.

5. Tom LaMarra, "Decision 2004?," The Blood Horse, 3 January 2004, 45.

6. The figures here were a consensus compilation of numerous articles. No single source or material produced the entire set of figures.

7. The Keeneland Association, Inc., "Racing," in Keeneland Association, Inc. Thoroughbred Racing and Sales 2002 Media Guide (Lexington, KY.: The Keeneland Association, Inc., 2002), 4.

8. Grade I races attract the best horses running at the time. There are Grade II and Grade III stakes races that also attracts the top quality horses. Keeneland has added Grade I events over the years and as of 2004 holds six Grade I races during the combined spring and fall meetings.

9. There are more than one published copies of Keeneland's original prospectus. This quote came from a condensed version published in The Blood Horse magazine. Thomas B. Cromwell, ed., "New Plans for Lexington," The Blood Horse, 9 February 1935, 282.

10. Keeneland: Reflections on a Thoroughbred Tradition, ed. William Strode, "Keeneland: A Half Century of Racing" (Prospect, KY.: Harmony House, 1986), 42.

11. The figures on the Kentucky Derby, Preakness, Belmont winners came from The Keeneland Association, Inc., "Sales," in Keeneland Association, Inc. Thoroughbred Racing and Sales 2004 Media Guide (Lexington, KY.: The Keeneland Association, Inc., 2004), 213-215. 
12. Dubow, "High Stakes in the Bluegrass," 92.

13. Keeneland: Reflections on a Thoroughbred Tradition, ed. William Strode, "Keeneland: A Half Century of Racing" (Prospect, KY.: Harmony House, 1986), 43.

14. Tom LaMarra, ed., The Blood Horse, 27 December 2003, 7129.

15. The figures given here are a compilation of date from numerous sources. No single source produced the number of horses or the monetary figures.

16. Dubow, "High Stakes in the Bluegrass," 109.

17. Information on Kurt Becker came from The Kentucky Post, a daily newspaper in northern Kentucky. There is material on Becker in Keeneland's media guides, but the information here came from The Post. Mike Bass, "New Tradition for Keeneland," The Kentucky Post, 4 April 1997, C3.

18. Amber Scott, "Contact: Nick Nicholson," Southsider Magazine, April 2003, 30.

19. The Keeneland Association, Inc., "Contributions for 2003," in Keeneland Association, Inc. Thoroughbred Racing and Sales 2004 Media Guide (Lexington, KY.: The Keeneland Association, Inc., 2004), 221-224.

20. University of Louisville Local History Series, ed. Elva Ann Lyons, vol. 20, "Keeneland Race Track" (No publisher information given), 305.

21. Mike Bass, "New Tradition for Keeneland," The Kentucky Post, 4 April 1997, C3.

22. Scott, "Contact: Nick Nicholson," 30. 


\section{Endnotes-Conclusion}

1. Laura Hillenbrand, Seabiscuit: An American Legend New York, NY.: Random House, 2001), 273-274.

2. Ibid., 264.

3. John Rickards Betts, American Sporting Heritage: 1850-1950 (Reading, MA.: Addison-Wesley Publishing Company, 1974), 33.

4. The quote "America's model race track" is the phrase that became associated with Keeneland. The founding committee members, The Blood Horse and The Thoroughbred Record repeatedly referred to Keeneland as "America's model race track. The quote is not from any single source. 92.

5. Shane Dubow, "High Stakes in the Bluegrass," National Geographic, May 2003,

6. Elizabeth M. Simpson, The Enchanted Bluegrass (Lexington, KY.: Transylvania Press, 1938), 307.

7. The quote "a model racing plant" is a phrase that became associated with the founder's of Keeneland in numerous sources. It is used in quotes here to reflect the title of the Thesis and is not a quote from any single source.

8. Thomas B. Cromwell, ed., "Background: Editorial Notes," The Blood Horse, 27 April 1935, 551.

9. Thomas B. Cromwell, ed., "New Plans for Lexington," The Blood Horse, 9 February 1935, 282.

10. Deidre B. Biles, “A Dream Fulfilled,” The Blood Horse, 22 March 1986, 2136.

11. John F. Rooney, A Geography of American Sport: From Cabin Creek to Anaheim (Reading, MA.: Addison-Wesley Publishing Company, 1974), 14.

12. S.W. Pope, ed., The New American Sport History: Recent Approaches and Perspectives (Urbana and Chicago, IL.: University of Illinois Press, 1997), 1. 


\section{REFERENCES}

Adelman, Melvin L. A Sporting Time: New York City and the Rise of Modern Athletics, 1820-70. Urbana and Chicago, IL.: University of Illinois Press, 1986.

Alfange, Dean. The Horse Racing Industry. New York, NY.: Kensington Publishing Corporation, 1976.

Baker, William J. Sports in the Western World. Urbana and Chicago, IL.: University of Illinois Press, 1982.

Betts, John Rickards. American Sporting Heritage: 1850-1950. Reading, MA.: Addison-Wesley Publishing Co., 1974.

Case, Carole. The Right Blood: America's Aristocrats in Thoroughbred Racing. New Brunswick, N.J.: Rutgers University Press, 2001.

Clark, Thomas D. A History of Kentucky. Ashland, KY.: The Jesse Stuart Foundation, 1992.

Crist, Steven. The Horse Traders: Inside the Billion Dollar Breeding Industry that Rules Racing Today. New York, NY.: Norton Press, 1986.

Culver, Francis Barnum. Blooded Horses of Colonial Days: Classic Horse Matches in America Before the Revolution. Baltimore, MD.: Published by the author, 1922.

de la Grange, Baroness Ernest. Horse Racing Through the Ages: Some Facts and Figures. London: Studies Publications, 1932.

Estes, J.A., and Joe H. Palmer. An Introduction to the Thoroughbred Horse: Origin, Distribution, Breeding, Conformation, Uses. Lexington, KY.: The Blood Horse, 1942.

Faulconer, J.B. The Keeneland Story: A Quarter-Century of Racing in the Finest Tradition. Lexington, KY.: Thoroughbred Press, 1960.

Gerdy, John R. Sports: The All-American Addiction. Jackson, MS.: University Press of Mississippi, 2002. 
Hillenbrand, Laura. Seabiscuit: An American Legend. New York, NY.: Random House, 2001.

Hollingsworth, Kent. The Kentucky Thoroughbred. Lexington, KY.: University of Kentucky Press, 1976.

Howland, Joan S. A Legal Research Guide to American Thoroughbred Racing Law for Scholars, Practitioners, and Participants. Buffalo, NY.: W.S. Hein Press, 1998.

Jordan, Joe Speed. The Bluegrass Horse Country. Lexington, KY.: Transylvania Press, 1940.

Lancaster, Clay. Antebellum Suburban Villas and Rural Residences of Fayette County. Kentucky: And Some Outstanding Homes of Lexington; a Cartographic Guide to the Early Architecture of the Heart of the Bluegrass Country. Lexington, KY.: Published by the author, 1955 .

Levine, Peter. American Sport: A Documentary History. Englewood Cliffs, NJ.: Prentice Hall, Inc., 1989.

Lipsky, Richard. How We Play the Game: Why Sports Dominate American Life. Boston, MA.: Beacon Press, 1981.

Lohman, Jack, and Arnold Kirkpatrick. Successful Thoroughbred Investment in a Changing Market. Lexington, KY.: Thoroughbred Publishers, 1984.

Mackay-Smith, Alexander. Speed and the Thoroughbred: The Complete History. Lanham, MD.: Derrydale Press, 2000.

. The Colonial Quarter Race Horse. Richmond, VA.: Press of Whittet \& Shepperson, 1983.

Mangum, William Preston. A Kingdom for the Horse: The Legacy of R.A. Alexander and Woodburn Farms. Louisville, KY.: Harmony House, 1999.

Mrozek, Donald J. Sport and American Mentality: 1880-1910. Knoxville, TN.: The University of Tennessee Press, 1983.

Noverr, Douglas A., and Lawrence E. Ziewacz. The Games They Played: Sports in American History, 1865-1980. Chicago, IL.: Nelson-Hall Publishing, 1983.

Parker, Robert B. A Year at the Races. New York, NY.: Viking Press, 1990.

Pope, S.W., ed. The New American Sport History: Recent Approaches and Perspectives. Urbana and Chicago, IL.: University of Illinois Press, 1997. 
Radar, Benjamin. American Sports: From the Age of Folk Games to the Age of Spectators. Englewood Cliffs, NJ.: Prentice Hall, Inc., 1983.

- American Sports: From the Age of Folk Games to the Age of Televised Sports. Englewood Cliffs, NJ.: Prentice Hall, Inc., 1990.

Reiss, Steven A. The American Sporting Experience: A Historical Anthology of Sport in America. Champaign, IL.: Leisure Press, 1984.

- City Games: The Evolution of American Urban Society and the Rise of of Sports. Urbana and Chicago, IL.: University of Illinois Press, 1989.

Renau, Lynn S. Racing Around Kentucky. Louisville, KY.: Published by the author, 1995.

Rooney, John F. A Geography of American Sport: From Cabin Creek to Anaheim. Reading, MA.: Addison-Wesley Publishing Company, 1974.

Simon, Mary. Racing Through the Century: The Story of Thoroughbred Racing in America. Irvine, CA.: BowTie Press, 2002.

Simpson, Elizabeth M. The Enchanted Bluegrass. Lexington, KY.: Transylvania Press, 1938.

Spivey, Donald, ed. Sport in America: New Historical Perspectives. Westport, CN.: Greenwood Press, 1985.

Staples, Charles R. The History of Pioneer Lexington: 1779-1806. Lexington, KY.: University of Kentucky Press, 1996.

Stout, Nancy. Great American Thoroughbred Race Tracks. New York, NY.: Rizzoli International Publications, Inc., 1991.

Strode, William ed. Keeneland: A Half-Century of Racing. Louisville, KY.: Harmony House Publishers, 2000.

Sullivan, John Jeremiah. Blood Horses: Notes of a Sportswriter's Son. New York, NY.: Farrer, Straus, and Giroux Press, 2004.

Taulbot, Ray. Thoroughbred Horse Racing: Playing For Profit. New York, NY.: American Publishers, 1969.

Upton, Roger D. Newmarket and Arabia: An Examination on the Descent of Racers and Coursers. New York, NY.: Olms Presse, 1987. 
Wharton, Mary E., and Edward L. Bowen, eds. The Horse World of the Bluegrass.

Lexington, KY.: Bradford Press, 1980.

Willett, Peter. Makers of the Modern Thoroughbred. Lexington, KY.: University of Kentucky Press, 1986.

. The Classic Racehorse. Lexington, KY.: University of Kentucky Press, 1982.

- The Thoroughbred. New York, NY.: Putnam Press, 1970.

Wright, Jr., John D. Lexington: Heart of Bluegrass. Lexington, KY.: LexingtonFayette County Historic Commission, 1982.

\section{Primary Sources}

Bruce, Sanders Dewees. The Horse Breeders Guide and Handbook: Embracing OneHundred Tabulated Pedigrees of the Principal Sires, With Full Performances of Each and Their Best Get, Covering the Season of 1883, With a Few Other Distinguished Dead Ones. New York, NY.: Office of Turf, Field and Farm, 1883.

Kentucky Association, Inc. "A Souvenir from the Kentucky Association: Centennial Meeting, Spring 1926, 10 Days Racing." Lexington, KY.: Published by the Kentucky Association, Inc., 1926.

Perrie, William Henry, ed. History of Fayette County, Kentucky. Chicago, IL.: O.L. Baskin \& Co., 1882.

Ridgeway, William. The Origin and Influence of the Thoroughbred Horse. Cambridge, MA.: University Press, 1905.

Speed, John Gilmer. The Horse in America: A Practical Treatise on the Various Types Common in the United States, with Something on Their History and Varying Characteristics. New York, NY.: McClure, Phillips \& Co., 1905.

The Lexington Leader. 15 October 1936.

Wallace, John H. The Horse of America in his Derivation, History, and Development New York, NY.: Published by the author, 1897.

Webster, Henry Kitchell. The Thoroughbred. New York, NY.: A.L. Burt, 1917. 


\section{Theses, Dissertations and Research Papers}

Rieser, Marjorie. "Horse Racing in central Kentucky and Jefferson County (with special reference to Churchill Downs." Master's essay, University of Louisville, 1944.

Sims, Ann. "Keeneland Race Track." English essay, Department of English, University of Louisville, 1941.

\section{Periodicals and Newspapers}

Horse and Horsemen.

Keeneland Magazine.

Keeneland Media Guide 2002.

Keeneland Media Guide 2004.

National Geographic. May 2003.

Southsider Magazine. April 2003.

The Blood Horse.

The Courier-Journal (Louisville, KY.).

The Cincinnati Post. 4 April 1997.

The Lexington-Herald Leader.

The Spirit of the Times.

The Thoroughbred Record. 


\section{CURRICULUM VITAE}

NAME: $\quad$ Scott Anthony Carmony

ADDRESS: 4653 Hathway Drive

Lexington, KY 40515

DOB: $\quad$ Cincinnati, Ohio - July 25, 1967

EDUCATION

\& TRAINING: $\quad$ B.A., History

University of Louisville 1986-1993

M.A., History

University of Louisville

1995-2004

AWARDS: Phi Alpha Theta-Gray's College Bookstore Essay Contest 1996 